Linköping Studies in Science and Technology

Dissertation No. 2061

\title{
Closing nutrient cycles
}

Usman Akram

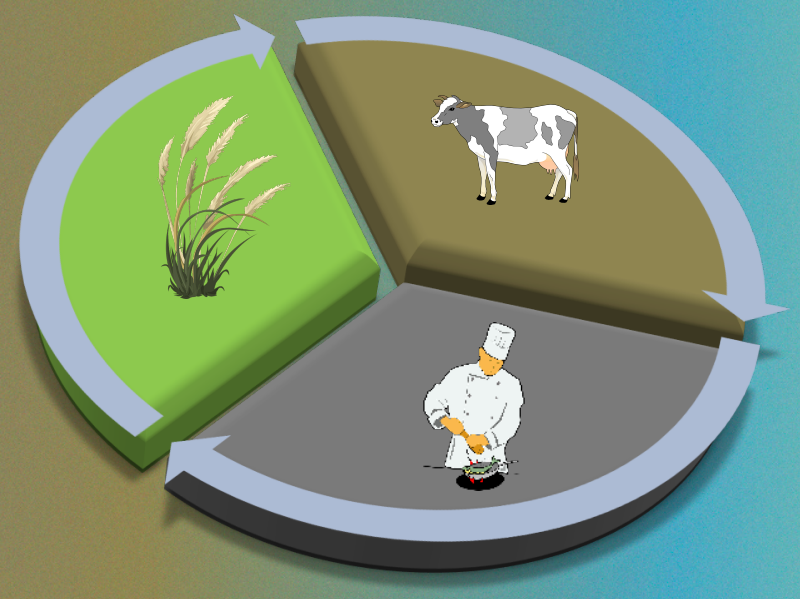


Linköping Studies in Science and Technology

Dissertation, No. 2061

\title{
Closing nutrient cycles
}

\author{
Usman Akram
}

M.U UNKNDENG

Theoretical Biology (TEOBI)

Linköping University, SE-581 83 Linköping, Sweden

Linköping 2020 


\section{Closing nutrient cycles}

Linköping Studies in Science and Technology

Dissertation, No. 2061

ISBN: 978-91-7929-875-3

ISSN $0345-7524$

Copyright $\odot 2020$ Usman Akram unless otherwise noted Printed by LiU-Tryck, Linköping 2020 
To my Father and Mother! It is all because of you! 


\section{Contents}

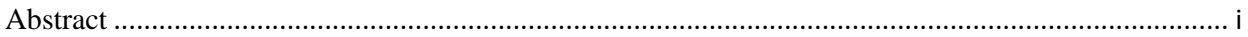

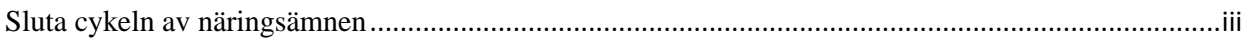

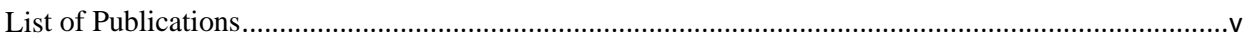

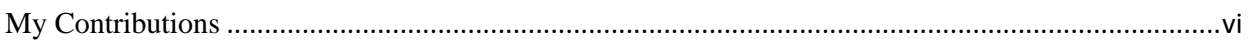

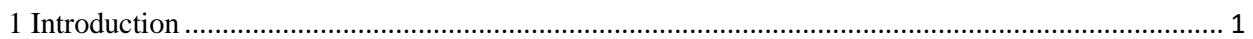

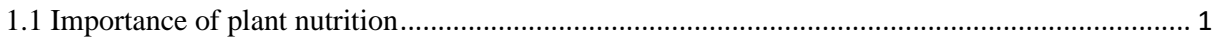

1.2 Scientific understanding of plant nutrition mechanisms ................................................... 2

1.3 Challenges to sustaining nutrient supply to an increasing food demand ................................ 4

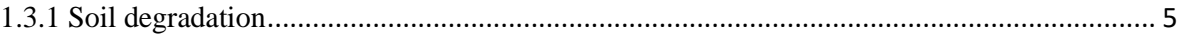

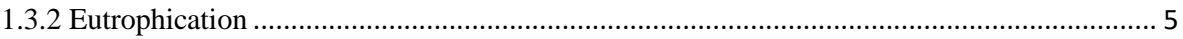

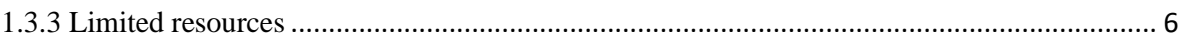

1.4 Need for nutrient recycling and increasing distances between supply and demand.................... 6

1.4.1 Previous work on the spatial separation of excreta supply and crop demand ...................... 7

1.4.2 Previous work on redistribution of excreta................................................................. 8

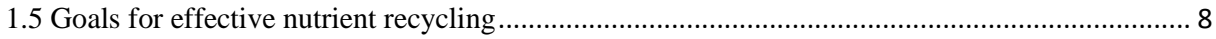

1.5.1 Estimating excreta resources compared to crop nutrient need ......................................... 8

1.5.2 Adjusting the recycling strategies at local scales .................................................... 9

1.5.3 Finding ways to minimize the costs of complete excreta recycling in a country ................ 9

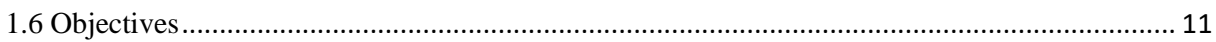

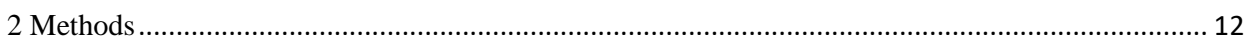

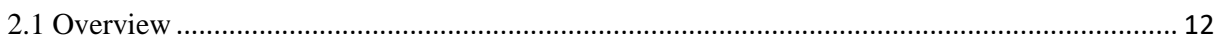

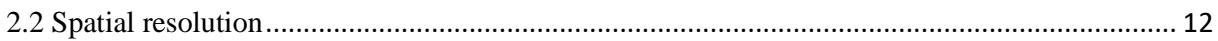

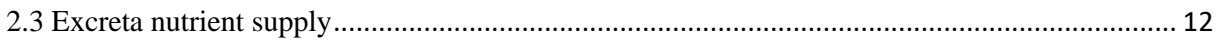

2.3.1 Losses from excreta ................................................................................................. 14

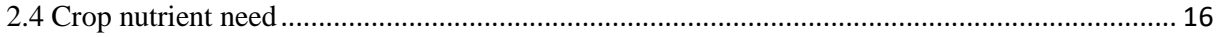

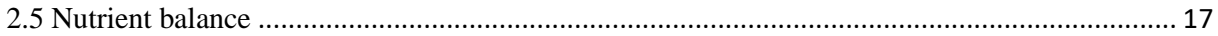

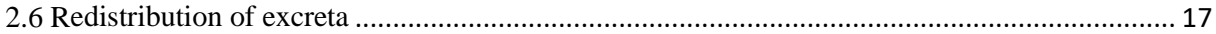

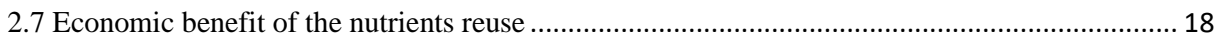

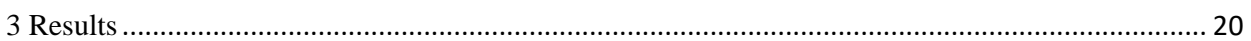

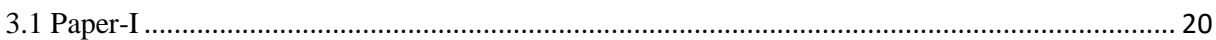

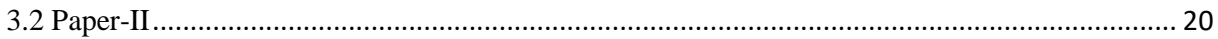

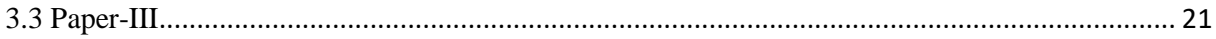

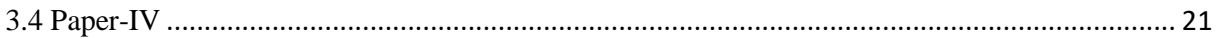

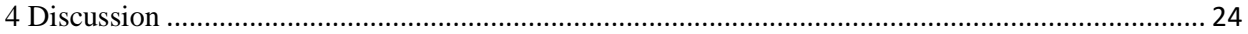


4.1 Global dilemma of reducing nutrient flows vs. meeting human food needs 24

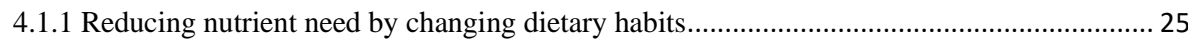

4.1.2 Redistribution of the use of nutrients - a global challenge .................................................. 25

4.2 Spatial separation -adjusting recycling strategies at local scales................................................. 26

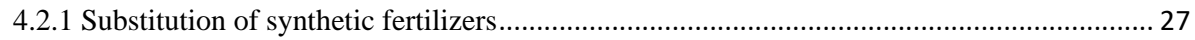

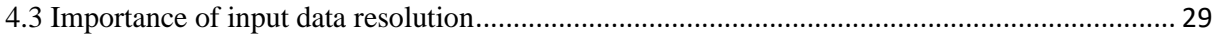

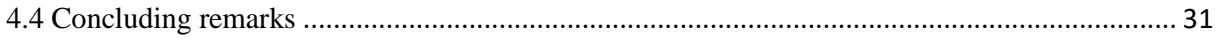

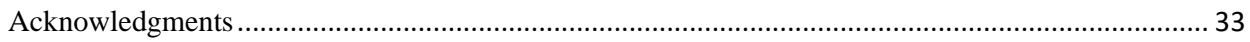

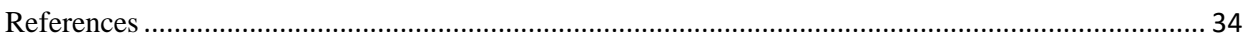




\begin{abstract}
Adequate and balanced crop nutrition - with nitrogen $(\mathrm{N})$, phosphorus $(\mathrm{P})$, and potassium $(\mathrm{K})$ - is vital for sustainable crop production. Inadequate and imbalanced crop nutrition contributes to the crop yield gaps - a difference in actual and potential crop yield. Yield gap is one of the many causes of insufficient food production, thus aggravating hunger and malnourishment across the globe. On the other hand, an oversupply of nutrients is highly unsustainable, in terms of both resource conservation and global environmental health. A decreasing excreta recycling in crop production is one of the many reasons for nutrient imbalances in agriculture. Previous studies show that increasing agricultural specialization leads to spatial separation of crop and animal production. Increasing distance between excreta production and crop needs is one of the leading factors that cause reduced excreta recycling. Studies focusing on excreta recycling show that a substantial barrier to a more efficient excreta nutrient reuse is the expensive transportation of bulky volumes of excreta over long distances. In order to overcome that barrier, more detailed spatial estimates of distances between excreta production and crop nutrient needs, and the associated costs for complete excreta transport in an entire country are needed. Hence, the overall aim of this thesis was to quantify the amount of nutrients in the excreta resources compared to the crop nutrient needs at multiple scales (global, national, subnational, and local), and to analyze the need for excreta transports, total distances and costs, to meet the crop nutrient needs in a country.
\end{abstract}

On the global scale, annual (2000-2016) excreta supply (livestock and human) could provide at least $48 \%$ of N, $57 \%$ of P, and $81 \%$ of K crop needs. Although excreta supply was not enough to cover the annual crop nutrient needs at the global scale, at least 29 countries for $\mathrm{N}, 41$ for P, and 71 for $\mathrm{K}$ had an excreta nutrient surplus. When including the annual use of synthetic fertilizers, at least 42 additional countries had a $\mathrm{N}$ surplus, with the equivalent figures for $\mathrm{P}$ being 17 countries, whereas 8 additional countries attained a K surplus. At the same time, when accounting for the use of synthetic fertilizers, each year, at least 57 countries had an $\mathrm{N}$ deficit, 70 a $\mathrm{P}$ deficit, and 51 countries a $\mathrm{K}$ deficit, in total equivalent to $14 \%$ of global $\mathrm{N}$ and $16 \%$ of each $\mathrm{P}$ and $\mathrm{K}$ crop needs. The total surplus in other countries during the period was always higher than the deficit in the countries with net nutrient deficits, except for $\mathrm{P}$ for some years. Unfortunately, both the deficits of the deficit countries and surpluses of the surplus countries were increasing substantially during the 17 years. Such global divergence in nutrient deficits and surpluses have clear implications for global food security and environmental health.

A district-scale investigation of Pakistan showed that the country had a national deficit of 0.62 million tons of $\mathrm{P}$ and 0.59 million tons of $\mathrm{K}$, but an oversupply of $\mathrm{N}$. The spatial separation was not significant at this resolution; only $6 \%$ of the excreta $\mathrm{N}$ supply needed to be transported between districts. Recycling all excreta, within and between districts, could cut the use of synthetic $\mathrm{N}$ to $43 \%$ of its current use and eliminate the need for synthetic $\mathrm{K}$, but there would be an additional need of 0.28 million tons of synthetic $\mathrm{P}$ to meet the crop nutrient needs in the entire country. The need for synthetic fertilizers to supplement the recycled excreta nutrients would cost USD 2.77 billion. However, it might not be prohibitively expensive to correct for P deficiencies because of the savings on the costs of synthetic N, and K. Excreta recycling could 
promote balanced crop nutrition at the national scale in Pakistan, which in turn could eliminate the nutrient-related crop yield gaps in the country.

The municipal-scale investigation using Swedish data showed that the country had a national oversupply of 110,000 tons of N, 6,000 tons of P, and 76,000 tons of K. Excreta could provide up to $75 \%$ of $\mathrm{N}$ and $81 \%$ of $\mathrm{P}$, and more than $100 \%$ of the $\mathrm{K}$ crop needs in the country. The spatial separation was pronounced at the municipal scale in the country. Just $40 \%$ of the municipalities produced over $50 \%$ of the excreta $\mathrm{N}$ and $\mathrm{P}$. Nutrient balance calculations showed that excreta recycling within municipalities could provide $63 \%$ of the $\mathrm{P}$ crop needs. Another $18 \%$ of the $\mathrm{P}$ crop needs must be transported from surplus municipalities to deficit municipalities. Nationally, an optimized reallocation of surplus excreta $\mathrm{P}$ towards the $\mathrm{P}$ deficit municipalities would cost USD 192 million for a total of 24,079 km truck transports. The cost was 3.7 times more than the total NPK fertilizer value transported, and that met the crop nutrient needs. It was concluded that Sweden could potentially reduce its dependence on synthetic fertilizers, but to cover the costs of an improved excreta reuse would require valuing the additional benefits of recycling.

An investigation was also done to understand the effect of the input data resolution on the results (transport needs and distances) from a model to optimize excreta redistribution. The results showed that the need for excreta transports, distances, and spatial patterns of the excreta transports changed. Increasing resolution of the spatial data, from political boundaries in Sweden and Pakistan to 0.083 decimal grids (approximately $10 \mathrm{~km}$ by $10 \mathrm{~km}$ at the equator), showed that transport needs for excreta-N increased by $12 \%$ in Pakistan, and the transport needs for excreta-P increased by $14 \%$ in Sweden. The effect of the increased resolution on transport analysis showed inconsistency in terms of the excreta total nutrient transportation distance; the average distance decreased by $67 \%$ (to $44 \mathrm{~km}$ ) in Pakistan but increased by $1 \mathrm{~km}$ in Sweden. A further increase in the data resolution to $5 \mathrm{~km}$ by $5 \mathrm{~km}$ grids for Sweden showed that the average transportation distance decreased by $9 \mathrm{~km}$. In both countries, increasing input data resolution resulted in a more favorable cost to fertilizer value ratios. In Pakistan, the cost of transport was only $13 \%$ of the NPK fertilizer value transported at a higher resolution. In Sweden, the costs decreased from 3.7 (at the political resolution) to slightly higher than three times of the fertilizer value transported in excreta at the higher data resolution.

This Ph.D. thesis shows that we could potentially reduce the total use of synthetic fertilizers in the world and still reduce the yield gaps if we can create a more efficient recycling of nutrients both within and between countries, and a more demand adapted use of synthetic fertilizers. 


\section{Sluta cykeln av näringsämnen}

Livsmedelsproduktion är grunden för vårt samhälle idag och för den utveckling som skett det senaste århundrandet. Idag är vi åtta miljarder människor i världen med en produktion och handel med livsmedel, där knappt en miljard lever under hunger och svält. Inom de närmaste decennierna förväntas världens befolkning fortsätta växa och stanna av på omkring 11 till 12 miljarder människor under senare hälften av 2000-talet. För att klara livsmedelsförsörjningen bättre idag, och ännu mer så i framtiden, krävs att vi hittar former för att återföra skördade näringsämnen, som fosfor, kväve och kalium, tillbaka till åkermarken. Många av dessa näringsämnen är ändliga resurser som dessutom bidrar till övergödning om de läcker ut till andra habitat. I dag återfinns det mesta av dessa näringsämnen i gödsel, mänsklig exkreta och rötslam från avloppsreningsverk. Avhandlingen har studerat förutsättningarna för att sluta en större del av näringsämnens cykler i Sverige och Pakistan genom återföring av gödsel och mänsklig exkreta till jordbruksmark, samt utifrån detta även dragit slutsatser om de globala förutsättningar och effekterna av att sluta kretslopp för näringsämnen.

Effekterna av att förbättra återförsel av näringsämnen till åkermark innefattar en minskad belastning i miljön som resultat av minskad användning av handelsgödsel, minskad användning av energi för produktion av handelsgödsel, samt framför allt ökade möjligheter för en långsiktigt hållbar hög skörd på åkerarealen. Det finns dock energikostnader vid återförsel av näringsämnen till följd av många och tunga transporter. Avhandlingen har därför analyserat transportkostnader för effektiv återvinning av näringsämnen från djurhållning och mänsklig exkreta och hur stor del av gödselbehovet som kan täckas av dessa återförda näringsämnen. Speciellt har avhandlingen också studerat hur viktigt det är att ta hänsyn till i vilken skala man skall studera problemet, dvs om det är data på gödselbehov och tillgång som är lokala - ända ner på enskilda fält och gårdar - regionala eller nationella som man skall utgå från när man söker efter effektiva lösningar för att sluta näringsämnes cykler.

Resultaten visar att större delen av gödselbehovet i både Pakistan och Sverige kan täckas genom återvinning av stallgödsel och mänsklig exkreta. I Sverige kan $81 \%$ av fosforbehovet täckas på det viset. Transporterna sker i första hand inom kommuner, $63 \%$ av behovet, medan de resterande $18 \%$ av behovet som kan täckas kräver transporter som är längre och sker mellan kommuner. Kostnaden för transporterna är däremot höga och motsvarar mer än tre gånger kostnaden för motsvarande handelsgödsel. I Pakistan är kostnadsbilden annorlunda, bl.a. eftersom lönekostnaderna är lägre och handelsgödsel är dyrare än i Sverige. Avhandlingen visar att kostnaden för transporter av gödsel i Pakistan skulle motsvara enbart $13 \%$ av kostnaden för motsvarande mängd handelsgödsel. Det mesta av återförandet av näringsämnen sker inom distrikt, till exempel är det bara $6 \%$ av kvävebehovet som behöver täckas av transporter utanför distrikten. Pakistans handelsgödselanvändning, och därmed kostnad för detta, skulle vid en effektiv återvinning av näringsämnen kunna reduceras ned till $43 \%$ av dagens kostnader för kvävegödsel, för fosfor behövs det 0.28 miljoner ton och behovet av kaliumgödsling skulle helt försvinna. Det krävs därmed handelsgödsel motsvarande 2.77 miljarder USD, vilket till del skulle kunna kompenseras av minskade totala kostnader för kväve- och kaliumgödsel. En sådan återföring av näringsämnen i Pakistan skulle också medföra en högre gödseltillförsel till jordbruket och därmed en möjlighet att reducera skördegapet i landet. Skördegapet i Pakistan 
är betydande med veteskördar kring 25-30\% av de möjliga, och dessa skördegap anses bero just på för små gödselgivor. Pakistan har också tydliga problem med livsmedelsförsörjning på grund av dagens skördegap med $20 \%$ av en befolkning på 200 miljoner som är undernärda. För Sveriges del är produktionen och avkastningen per areal till följd av gödsling redan hög. En mer effektiv återförsel av näringsämnen i Sverige skulle därför i första hand bidra till att minska användning av handelsgödsel och därmed begränsa användning av ändliga resurser som fosfor. Analyserna i avhandlingen visar till exempel att i Sverige skulle användning av fosfor som handelsgödsel kunna minska med $67 \%$ om återförsel av stallgödsel och mänsklig exkreta effektiviserades.

Analyser av globala data för år 2000 - 2016 visar att den årliga tillgången på näring i gödsel (från djur och människor) motsvarar minst $48 \%$ av grödornas $\mathrm{N}$ behov, $57 \%$ av $\mathrm{P}$ behovet och $81 \%$ av K behovet. Även om den total mängden näring i stallgödsel och mänsklig exkreta inte räcker för att täcka det årliga globala behovet av näring, så visar data på ett överskott på $\mathrm{N} \mathrm{i}$ minst 29 länder, ett överskott på P i minst 41 länder och 71 länder har ett K-överskott i stallgödsel och exkreta. Om man dessutom räknar in användningen av handelsgödsel blir det ytterligare 42 länder som har överskott på N, 17 länder till med P-överskott och 8 ytterligare med K- överskott. En stor del av resterande länder har ett underskott av näringsämnen (när man summerar gödsel, mänsklig exkreta och handelsgödsel), 57 länder har brist på N, 70 länder behöver mer $\mathrm{P}$ och 51 har brist på $\mathrm{K}$ i sitt jordbruk, och har därmed lägre skördar än möjligt. Det totala överskottet av näringsämnen i de andra länderna under denna period motsvarar dock rätt väl den brist som länder med underskott uppvisar. Tyvärr är trenden den att de länder som visade på överskott av näringsämnen år 2000 har sammantaget tydligt ökat på överskottet till 2016, medan även underskotten har ökat i flera av länderna med bristande tillförsel av N, P eller K. Sådana globala obalanser har tydliga implikationer för den framtida matförsörjningen och för miljön.

Avhandlingen visar att vi idag skulle kunna använda mindre handelsgödsel totalt i världen, och ändå reducera de skördegap som finns, om vi skapar en effektiv återförsel av näringsämnen såväl inom som mellan länder och ett mer behovsanpassat användande av handelsgödsel. 


\section{List of Publications}

I. Akram, U., Metson, G. S., \& Wennergren, U., 2020. Towards closing global yield gaps through excreta recycling. Manuscript

II. Akram, U., Metson, G. S., Quttineh, N. \& Wennergren, U., 2018. Closing Pakistan's Yield Gaps Through Nutrient Recycling. Front. Sustain. Food Syst.2, 1-14.

III. Akram, U., Quttineh, N-H., Wennergren, U., Tonderski, K., and Metson, G. S., 2019. Enhancing nutrient recycling from excreta to meet crop nutrient needs in Sweden-a spatial analysis. Sci. Rep.

IV. Akram, U., Quttineh, N.-H., Wennergren, U., Tonderski, K., Metson, G.S., 2019. Optimizing Nutrient Recycling From Excreta in Sweden and Pakistan: Higher Spatial Resolution Makes Transportation More Attractive. Front. Sustain. Food Syst. 3:50 


\section{My Contributions}

I. UA collected and analyzed data, was responsible for formulating questions and aim of the manuscript, and for drafting the manuscript.

II. UA collected and analyzed data, formulated questions, and made a major contribution in producing and interpreting the results and writing the manuscript

III. UA collected and analyzed data, participated in formulating the aim of the paper, and made a major contribution in producing and interpreting the results and writing the manuscript

IV. UA collected and analyzed data, participated in formulating the questions, and made a major contribution in producing and interpreting the results, and writing the manuscript 


\section{Introduction}

\subsection{Importance of plant nutrition}

Plants need seventeen essential nutrients to complete their life cycle (Mahler, 2004). Depending on the quantity of a nutrient needed, these are categorized into macronutrients and micronutrients. Macronutrients are needed in relatively larger amounts, compared to micronutrients. Each nutrient has a vital role in plant growth.

- Nitrogen $(\mathrm{N})$ is an integral part of the plant cells. It constitutes plant proteins, hormones, and chlorophyll.

- Phosphorus (P) plays a vital role in transferring energy from the sunlight to the plant tissues. Specifically, electrons in the molecules of chlorophyll are activated by the sunlight (red and blue light). The excited electrons transfer energy to ADP and NADP (P-containing molecules), which then convert into ATP and NADPH. ATP and NADPH drive many processes in living cells. $\mathrm{P}$ also accelerates early root growth and stimulates maturity in plants.

- Potassium (K) stimulates the process of the formation of starches, sugars, and oil in plants. It improves fruit quality. Further, it helps the movements of these elements within the plants. It increases the vigor of plants and helps increase disease resistance.

$\mathrm{N}, \mathrm{P}$, and $\mathrm{K}$ three of the six macronutrients are mainly obtained from the soil. The main source of these nutrients in soils is the parent material that is the sedimentary rocks from which the soils are formed (Singh and Schulze, 2005). N could also be supplied from the atmosphere through symbiotic $\mathrm{N}$ fixation (plants harbor a special kind of bacteria (rhizobia), which could fix the atmospheric $\mathrm{N}_{2}$ into plant-available ammonia $\left(\mathrm{NH}_{3}-\mathrm{N}\right)$ form in a mutualistic relationship with plants (James, 2016; Mylona et al., 1995)). Plant growth largely depends on the nutrients available in soils. Soil nutrients deficiency can have a large impact on plant growth: in agriculture, it can result in reduced crop yield (Morgan, 2013). Crop yield is defined as is the weight of harvested crop products at the standard moisture content (e.g., grains) per unit of the harvested area for a crop (Fischer, 2015). Crop yield is usually represented as metric tons per hectare (abbreviated as tons per ha). Lower crop yields than expected per unit of a land area are defined as crop yield gaps. More specifically, a yield gap is a difference between potential yield and actual yield in some specific environment (Fischer, 2015). Potential yield of a region is a measure of yield of the best cultivar under the best agronomic management in the absence of manageable biotic and abiotic stresses (Fischer, 2015). Soil nutrient deficiency is one of the many causes of crop yield gaps (Van Ittersum et al., 2013). In many regions across the globe, the nutrient supply to agriculture needs to increase (in addition to water), because it is crucial to close the crop yield gaps (Mueller et al., 2013; Pradhan et al., 2015).

Crop nutrition is increasingly important in feeding the human population. One way is to provide nutrients from external sources, but that has some serious negative impacts. For example, continued mining of limited P resources (Cordell et al., 2009) and fossil energy resources required for industrial $\mathrm{N}$ fixation (Chen et al., 2019) is threatening the future availability of these resources. Moreover, if soils are oversupplied with nutrients, the resulting nutrient emissions cause environmental pollution (Mccrackin et al., 2018). Another way is to increase 
nutrient use efficiency in agriculture (Hawkesford, 2012). A third way is to enhance nutrient recycling through more efficient use of nutrients resources in excreta (Mccrackin et al., 2018).

It has become increasingly important to increase nutrient use efficiency in order to reduce resource depletion and control nutrient emissions for the benefit of the environment. Therefore, in order to sustain food security and environmental integrity, there is a need to enhance our understanding of quantitative estimates of crop nutrient need and nutrient supplies (excreta and synthetic) at different scales. Results from such research are needed to enhance the knowledge about possibilities to increase nutrient recycling between the areas of crop nutrient need and those with excreta nutrient production. This thesis analyzes the potential to correct regional nutrient imbalances through excreta transports at different spatial scales. More specifically, the Papers in the thesis investigate the potential of excreta recycling to facilitate resource use efficiency, reduce nutrient emissions, and remove the crop yield gaps at different scales.

\subsection{Scientific understanding of plant nutrition mechanisms}

Humans began their history as hunter-gatherers, meaning there was no agriculture or animal husbandry. Food needs were met by wild plants and hunting wild animals (Price and Gebauer, 1995). The Neolithic Revolution in 7,000 BC introduced the widespread use of metal tools to manipulate the soils. This ability to manipulate the soils enabled the hunters to become farmers; they began to harness the earth by cultivating plants and domesticating animals (Weisdorf, 2005). These ancient farmers had the idea that in order to grow, plants need food. They were interested in understanding the phenomena of plant growth. Homer, the legendary author of the Iliad and the Odyssey, in the $8^{\text {th }}$ century BC, wrote that plant growth could be improved by applying excreta (Antonkiewicz, 2016). It was also common knowledge among the Ancient Greeks that excreta and compost improve plant growth, meaning they had a basic understanding of soil fertility (Montgomery, 2007). Aristotle, in the $4^{\text {th }}$ century BC, believed that soil prepares food for plants in the form of organic matter, and plants take up the organic matter from the soil through roots in the form of substances that are present in the plant tissue (Lieth, 1975). During the $1^{\text {st }}$ century $\mathrm{BC}$, agriculture expanded to large acreages, and excreta, ashes, lime, marl, bones, and gypsum were conventional fertilizers to improve plant growth (Antonkiewicz, 2016). Even the 'specialization' in agriculture began, as early as the $1^{\text {st }}$ century $\mathrm{BC}$, leading primarily to extensive scale cultivation of grapevines, olives, and cereals to meet the food need of the army in the Roman Empire (Mikołajczyk, 2009).

Aristotle's concept of the soil-plant relationship was correct, but the idea of plant nutrition was wrongly interpreted, and the idea was held almost for 1800 years (Lieth, 1975). In 1450, Nicolai de Cusa replaced Aristotle's concept of 'organic matter' with 'water,' that is, 'the water thickens within the soil, sucks off soil substances which are then, by the action of the sun, condensed to plant biomass" (Lieth, 1975). Nicolai's view, for the first time, emphasized that there is a connection between water and plant. This view, after about 150 years, provided the basis for the design of van Helmont's experiment (Lieth, 1975). Like many other scientists, van Helmont was curious to know what can be used as food for plant growth. He designed an experiment on a willow tree and concluded that the water condensed to form plant biomass. About 100 years after van Helmont's experiment, Joseph Priestley (an English minister) conducted an experiment, which for the first time gave the insight that there is interaction 
between plants and air (Lieth, 1975). Later, the Dutch scientist Jan Ingenhousz showed that the interaction between plants and air only occurs in the presence of light (Starck, 2014). The research conducted by van Helmont, Priestley, and Ingenhousz guided the work by De Saussure (Spoehr, 1919), who studied the gas exchange of plants and gave the equation of photosynthesis, which still applies.

$$
\begin{gathered}
6 \mathrm{CO}_{2}+6 \mathrm{H}_{2} \mathrm{O}=\mathrm{C}_{6} \mathrm{H}_{12} \mathrm{O}_{6}+6 \mathrm{O}_{2} \\
\text { Carbon dioxide }+ \text { water }=\text { sugars }+ \text { oxygen }
\end{gathered}
$$

According to Métioui et al. (2016), De Saussure introduced the concept of plant nutrition as he explained that the primary source of carbon in a plant is the atmosphere, while the ash components and water come from the soil. In other words, De Saussure, in addition to justifying the role of oxygen and carbon dioxide in the plant processes, also emphasized the role of nutrients taken up by plants from the soil.

The $18^{\text {th }}$ and $19^{\text {th }}$ centuries saw advances in our understanding of the processes of plant nutrition. According to Antonkiewicz (2016), two theories of plant nutrition emerged. (1) The humus theory of plant nutrition (Albrecht Daniel von Thaer (1752-1828)); (2) the theory of mineral plant nutrition (Justus von Liebig (1803-1873)). Von Thaer believed that humus and water have the primary role in plant nutrition and that minerals do not have a direct role in plant nutrition (PAULI, 1933). He believed that minerals play only a supporting role in forming the humic compounds. Therefore, he believed that the amount of humus is the main factor that defines soil fertility. Justus von Liebig did not agree with the humus theory as he believed that not humus but mineral salts are taken up with water by roots from the soil, and carbon dioxide assimilated from the air in the photosynthesis process are the direct food for plants (Sparks, 2006).

Von Liebig wrongly believed that the ash component defines the value of excreta and that $\mathrm{N}$ is not essential in plant nutrition. French chemist and agronomist Jean Baptiste Boussingault (1802-1887) criticized von Liebig's conviction regarding N (Aulie, 1970). Boussingault, through his research, showed that plant yield is lower in soils deficient in N. Therefore, he believed that $\mathrm{N}$ is vital to harvesting higher crop yields. Apart from showing the role of $\mathrm{N}$ in plant growth, Boussingault was the first scientist who paid attention to the recycling of nutrients in nature (Aulie, 1970). It is important to note that Boussingault formulated the theory of mineral plant nutrition before Justus von Liebig (before 1840), but unfortunately, it was not published (Antonkiewicz, 2016). It took many years of research before Boussingault's views on the importance of $\mathrm{N}$ were coupled with Liebig's view on the importance of ash components in plant nutrition, which then formed the basis of today's mineral plant nutrition.

Liebig and Boussingault are the founders of modern agricultural chemistry. Liebig explained the importance of mineral fertilization in a lecture: "Rome has thrown the entire fertility of Sicily into the gutter" (Antonkiewicz, 2016). In other words, he wanted to say that Rome imported minerals contained in the grains from Sicily, and those minerals, instead of returning to the soil through excreta recycling, ended up into municipal waste. Therefore, the Sicilian soils became the nutrient deficient, and the region became the poorest in the world. Initially, as discussed above, Justus von Liebig did not agree with the humus theory, but later he began to 
appreciate the role of humus to increase fertility (Wilson, 2014). Today it is common knowledge that natural and organic fertilizers are essential in addition to synthetic fertilizers to maintain and increase soil fertility.

In 1842, German scientist Carl Sprengel (1787-1859) devised the 'theory of minimum' in agricultural chemistry (Antonkiewicz, 2016). This theory is now known as 'Liebig's law of the minimum.' According to this, plant growth is limited by the essential nutrient at the lowest concentration. It is important to note that Liebig, as a known researcher, popularized this theory, although the theory was formulated by Sprengel (van der Ploeg et al., 1999). Liebig's theory of mineral plant nutrition was a critical discovery in agricultural sciences. The discovery of the 'Law of mineral plant nutrition' and the 'Law of the minimum' laid the foundation for the manufacturing of synthetic fertilizers (Antonkiewicz, 2016). In 1848, the first superphosphate factory was founded in Liverpool, and about a half-century later, the phenomenon of the catalytic production of $\mathrm{NH}_{3}$ from atmospheric $\mathrm{N}$ was revealed (by Fritz Haber (1868-1934) and Carl Bosch (1874-1940)), which led to the production of $\mathrm{N}$ fertilizers (Chen et al., 2019).

\subsection{Challenges to sustaining nutrient supply to an increasing food demand}

The real benefits of understanding the plant nutrition processes and being able to manufacture synthetic fertilizers could only be fully realized in the presence of high-yielding varieties (Hazell, 2010). Rapidly increasing population in the world and the need to supply food gave rise to a challenge in the field of plant breeding and genetics, to develop the plant varieties that were more responsive to plant nutrients (Hazell, 2010). Between the 1960s and 1970s, the period referred to as the green revolution, agricultural production with the use of synthetic fertilizers and pesticides along with improved irrigation techniques and the cultivation of highyielding varieties of wheat, maize, potatoes and rice with high protein content gave the technological capacity to feed the earth's population. Only in developing countries, between 1960 and 2000, the yield for wheat increased by $208 \%$, for rice by $109 \%$, for maize by $157 \%$, and for potatoes by $78 \%$ (FAO, 2004a). Although most of these achievements are attributed to the improvement in crop germplasm, the best germplasm is of no use without the appropriate agricultural technologies. For example, the development of wheat germplasm in Kenya involved a trait selection based on nutrient and water use efficiency (Dubin and Brennan, 2010). In other words, the achievements of the Green Revolution would not have been possible without proper and adequate access to fertilizers and water, as well as improved agronomic practices. As such, the significant achievements of increased food production correspond to increased use of synthetic fertilizers. For example, in Asia, the use of synthetic fertilizers per hectare was increased by 616\% between 1970 and 1995 (Rosegrant and Hazell, 2000).

Although knowledge of plant nutrition and manufacturing synthetic have made a considerable contribution to global food supplies, more than 800 million people lack adequate access to food even today (SOFI, 2005; UN, 2006). The global human population is increasing, and by 2050 there will be an estimated 2 to 2.5 billion new mouths to feed (FAO, 2009a). Future food supplies are now considered a global priority (UN, 2000; IFPRI, 2002b). As such, the rise in the global demand for food will increase the fertilizer need by $1.5 \%$ for N, $2.2 \%$ for P, and $2.4 \%$ for $\mathrm{K}$ in the coming five years (FAO, 2017). Limited use of fertilizers in crop production could cause declining crop yields and is already a major cause of food insecurity in poor regions. For 
example, in Sub-Saharan Africa, 30\% of the population is undernourished. The region has one of the lowest fertilizer application rates, and soil nutrient deficiency is widespread over $75 \%$ of the agricultural land, causing a substantial decline in crop yields (Smaling et al., 2006). Increased nutrients supply in lower soil fertility regions is essential to be able to harvest high crop yields. However, such increased nutrient supply from synthetic fertilizers is challenging, mainly because they are manufactured from limited fossil resources and are usually expensive.

Although nutrient deficit threatening food security is a problem in some countries, nutrient surplus mostly triggered from reduced excreta recycling is a major problem in some other countries (Bateman et al., 2011; Hanserud et al., 2015; Leinonen et al., 2019; Parchomenko and Borsky, 2018; Senthilkumar et al., 2012; van Dijk et al., 2016). Today, only a small proportion of global excreta is recycled back to crops (Cordell et al., 2009; Mihelcic et al., 2011; Sheldrick et al., 2003; van Puijenbroek et al., 2019). As it challenges the sustainability of food production, excessive nutrient input indirectly is a major threat to the future of global food security. The following are some common challenges related to excessive nutrient input in crop production.

\subsubsection{Soil degradation}

The detrimental impacts of an increased use of synthetic fertilizers were already noticed in the $20^{\text {th }}$ century (Antonkiewicz, 2016). Farmers realized a yield reduction per unit of increased fertilizer application during that time. It is important to note that the buffering and filtering capacity of soils play an important role in providing nutrients for plant growth. An overapplication, together with soil acidification, ${ }^{1}$ can affect the buffering and filtering capacity of soils and thus the soil's ability to provide nutrients to plants. In addition to the yield reduction, some studies highlighted that unbalanced and excessive fertilization is damaging the harvested crop quality ${ }^{2}$. Two new fertilizer laws in the 1960s in the field of plant nutrition were discovered by Andre Voisin (1903-1964), a French scientist (Antonkiewicz, 2016). First, the Law of the Maximum states that an excessive amount of available substance in soil limits the effectiveness of other substances, and thus causes a decrease in the crop yields. Second, the Law of the priority of biological quality states that the main goal of fertilizer use should be to improve the biological quality of the crop product, which is of higher importance than the yield. Antonkiewicz (2016) argues that in present-day agriculture, both those laws are as important as the law of plant nutrition and the law of the minimum.

\subsubsection{Eutrophication}

The increased use of synthetic fertilizers combined with nutrients in excreta and other wastes resulted in nutrient input being greater than crop nutrient needs in different parts of the world. The resultant surplus increased the nutrient losses to water bodies, causing water pollution, that is commonly known as eutrophication. Most of the scientific developments on eutrophication are quite recent, but the earliest date back to the 1950s (Lemley and Adams, 2019). During the 1970s and 1980s, a large amount of research was conducted into the causes and mechanisms underlying the process of eutrophication in the lakes in the northern hemisphere (Dillon and

\footnotetext{
${ }^{1}$ Soil acidification mainly caused by the atmospheric precipitation of acidifying gases or particles for example $\mathrm{SO}_{2}, \mathrm{NH}_{3}$ and $\mathrm{HNO}_{3}$, and due to the use of synthetic fertilizers containing these elements (Goulding, 2016).

${ }^{2}$ According to Andre Voisin, biological quality is defined as the amount of plant nutrients important for normal metabolism in an animal or human (Antonkiewicz, 2016).
} 
Rigler, 1974; Hecky and Kilham, 1988; Schindler, 1974; Vollenweider, 1968). Although it is a slow and natural process (Lampert \& Sommer, 1997), the rates of such enrichment have been accelerated mainly because of an increased application of synthetic fertilizers, intensified livestock farming and the subsequent nutrient losses (Svanbäck et al., 2019). The water bodies have limits to assimilate or buffer the nutrient input. Limnological models have been developed to assess nutrient flows at different scales, for example, $\mathrm{P}$ in wetlands, rivers, lakes, and marine systems (Robson, 2014). As a result, scientists have developed safety limits for nutrient input at relevant scales. In this context, planetary boundaries define maximum safe nutrient flows at the global scales (Carpenter and Bennett, 2011; De Vries et al., 2013; Rockström et al., 2009; Steffen et al., 2015).

\subsubsection{Limited resources}

It is a fact that synthetic fertilizers are manufactured directly or indirectly from limited fossil resources; for example, $\mathrm{P}$ from phosphate rock and synthesis of $\mathrm{N}$ depends heavily on the use of natural gas. It is a common belief among scientists and the general public that $\mathrm{P}$ reserves are scarce. $\mathrm{P}$ has an essential role in today's agricultural system, and any scarcity could result in a collapse of global food production and food security (Cordell et al., 2009). There is a continuous debate on the future availability of the phosphate rock. Some say that the $\mathrm{P}$ will reach its peak availability in a few years and others say the peak is yet come centuries ahead (Chowdhury et al., 2017; Edixhoven et al., 2014; Geissler et al., 2018). However, there is large consent in its future unavailability being a non-renewable resource, with fluctuating prices, and the total reserves located in a hand-full of countries. Similarly, for manufacturing of synthetic N, natural gas (that is also a limited fossil resource) is an essential component of the Haber-Bosch process (Chen et al., 2019).

\subsection{Need for nutrient recycling and increasing distances between supply and demand}

In natural terrestrial ecosystems, recycling is a natural phenomenon; an estimate shows that, in the case of $\mathrm{P}$, an atom recycles about 47 times in the ecosystem before it is lost to aquatic bodies (Leopold, 1943). In contrast, in the managed systems of food production, a larger proportion of current global nutrient surpluses come from unrecycled excreta resources (Cordell et al., 2009; Mihelcic et al., 2011; Sheldrick et al., 2003; van Puijenbroek et al., 2019). As such, the challenges discussed above suggest that there is a need to improve the use of nutrients to reduce both nutrient surpluses and deficits in today's agricultural system. In this context, an increased recycling of excreta nutrients (leading to reduced need for synthetic fertilizers) is an option to reduce the nutrient surplus and thus to solve some of these challenges (Withers et al., 2015a). However, increasing distances between areas of excreta production and crop nutrient need are unfavorable in terms of recycling of the excreta nutrients (Keplinger and Hauck, 2006; Nicholson et al., 2012; Westerman and Bicudo, 2005).

Historians believe that the spread of agriculture (Neolithic Revolution) had resulted in human settlements near the area of agricultural production (Lumen, 2020). In this respect, the introduction of agriculture is said to be the reason for the creation of cities. Evidently, in modern times, technical progress in the form of industrial production of synthetic fertilizers, improved crop varieties, and construction of irrigation canals facilitated the transformation of sparsely populated semi-arid areas into densely populated and intensified agricultural areas, for example, 
as in Punjab in India (Federico, 2009). Simultaneously, trading of agricultural commodities is as old as the agriculture itself. A recent study suggests a trade of wheat between Mesolithic people of Northern Europe with the Neolithic inhabitants of farther South (Smith et al., 2015). Trading might have transformed the subsistence farmers into market-oriented farmers. Commercialization of agriculture has probably given rise to specialized farming, i.e., farms became specialized either in crop or animal production. Cities and specialized animal farms are dependent on the inflow of food and fodder, respectively. Until the late nineteenth century, most of the food needs of the cities were provided from the nearby agricultural areas (Federico, 2009). In this context, probably the fodder need of farm animals was met from the nearby cultivated lands. Later, the invention of the refrigerator and improvement in transportation infrastructure enabled the transportation of food and feed materials over thousands of kilometers. The concentration of human populations in the form of significant urban settlements and the concentration of livestock production in the form of large factory farms resulted in larger amounts of excreta nutrients produced in the cities and at the farms. Excreta has high water content and lower nutrient concentrations compared to the synthetic fertilizers. Returning of large volumes of excreta is challenged, and these nutrients rarely reach the areas where they are needed.

\subsubsection{Previous work on the spatial separation of excreta supply and crop demand}

As it is vital to highlight the problem of reduced nutrient recycling, increased use of synthetic fertilizers, and increased nutrient losses, several studies have focused on analyzing the effect of spatial separation of crop nutrient need and excreta nutrient supply in different countries. These studies used both subnational boundaries, for example, using geographic borders of counties, municipalities, or parishes as well as self-defined local boundaries, for example, grids of a specific size in a country. More specifically, Hanserud et al. (2015) estimated spatial separation of crop P need and excreta P supply at the county scale in Norway (the average area of the counties is $29,437 \mathrm{~km}^{2}$ ). They found that the excreta $\mathrm{P}$ balance (excreta $\mathrm{P}$ supply minus crop $\mathrm{P}$ need) ranges between $-7.0 \mathrm{~kg} P$ per ha (in Østfold county) to $11.2 \mathrm{~kg} \mathrm{P}$ per ha (in Rogaland country) in the country. Senthilkumar et al. (2012) P flows and soil P budgets in agricultural production system at the scale of administrative regions in France (the average area of the regions is $35,172 \mathrm{~km}^{2}$ ). They showed that $\mathrm{P}$ use efficiency in the Brittany region is only half compared to the $\mathrm{P}$ use efficiency in Lorraine regions. They argued that the former region has heavy livestock excreta applications compared to the crop need. In contrast, the latter region has more mixed crop and livestock farming. Bateman et al. (2011) estimated the spatial separation of housed livestock excreta $\mathrm{P}$ supply and crop $\mathrm{P}$ need in eight regions of England (the average size of the regions is $16,302 \mathrm{~km}^{2}$ ). They found that the excreta $\mathrm{P}$ balance ranges between $-14.4 \mathrm{~kg}$ per ha to (in the eastern region) to $2.9 \mathrm{~kg}$ per ha (in the northwest region). Parchomenko and Borsky, (2018) investigated the livestock excreta $\mathrm{P}$ balance on the parish scale in Denmark (an average area of the parishes is $13 \mathrm{~km}^{2}$ ). They showed the $\mathrm{P}$ balance ranges between less than $10 \mathrm{~kg}$ per ha to more than $50 \mathrm{~kg}$ per ha. Leinonen et al., (2019) investigated the hotpots of livestock excreta $\mathrm{N}$ and $\mathrm{P}$ imbalances at the grid-scale $\left(4 \mathrm{~km}^{2}\right)$ in Scotland. They found that central and eastern regions have higher crop nutrient needs, while the higher livestock excreta production is located in the southern and northeastern regions of the country. 
Although these studies investigate spatial balance in a country at subnational and local scales, they did not include the estimates of total distances and costs of excreta transport to even-out the local surpluses and deficits of excreta. Instead, these studies suggest the need for an effective logistic system for excreta transports among the surplus and deficit regions of a country to enhance effective recycling (Bateman et al., 2011; Hanserud et al., 2015; Leinonen et al., 2019).

\subsubsection{Previous work on redistribution of excreta}

Many studies have investigated the economically viable distance for excreta transports in different countries. In the United States, the economically viable transport distances for excreta have been estimated to be $40 \mathrm{~km}$ for swine excreta (Keplinger and Hauck, 2006), 15 to $30 \mathrm{~km}$ for excreta from beef cattle (Paudel et al., 2009), $60 \mathrm{~km}$ for excreta from dairy production (Keplinger and Hauck, 2006), and $400 \mathrm{~km}$ for poultry excreta which is less bulky (Sharpley et al., 2016) and biosolids recovered from wastewater treatment plants may be transported over 2,000 km (Bergendahl et al., 2018). In Canada, this distance for excreta from beef cattle varies in terms of the intended reason of the excreta transports, i.e., 15 to $18 \mathrm{~km}$ in terms of meeting crop nutrient need (Freeze and Sommerfeldt, 1985), while this distance is only $12 \mathrm{~km}$ from an energy perspective (Pimentel and Pimentel, 2008). In Ireland, Fealy and Schröder, (2008) suggest 50 to $100 \mathrm{~km}$ as maximum hauling distance for swine excreta. Shigaki et al. (2006) report $15 \mathrm{~km}$ as the commonly economically acceptable radius for livestock excreta transports in Brazil. Some other studies have estimated the redistribution of excreta through optimization modeling. Transport optimization of surplus livestock excreta has been modeled at different spatial scales in different studies - for example, at county scale in the region of Chesapeake Bay Watershed in the United States, (Ribaudo et al., 2011), at district scale in the federal state of Lower Saxony, Germany (Biberacher et al., 2009; Warnecke et al., 2010), and the farm-scale in the state of Louisiana in the United States (Paudel et al., 2009).

Although these studies investigate excreta transports, they did not include the detailed spatial estimates of available excreta resources, crop nutrient need, need for excreta transports, and associated costs at a national scale in a country. However, based on excreta transport analysis made, these studies suggest that the pricing of the transports of excreta largely depends on the excreta characteristics (e.g., dry matter content) and other local factors, for example, regulations regarding excreta treatment and soil application rates, fuel prices, and transport infrastructure (Bloem et al., 2017; Flotats et al., 2009; Sharpley et al., 2016).

\subsection{Goals for effective nutrient recycling}

\subsubsection{Estimating excreta resources compared to crop nutrient need}

Global food demand will rise, which in turn increases the need for nutrients to produce more food (FAO, 2017). Increasing food production by closing crop yield gaps has to rely on increased nutrient input for many regions (Mueller et al., 2012; Pradhan et al., 2015). However, the nutrient supply in the form of synthetic fertilizers is constrained due to expensive, limited nutrient resources (Cordell et al., 2009; Schröder et al., 2010). Simultaneously, a nutrient surplus is a major environmental threat in many other parts of the globe (Granstedt, 2000; Mccrackin et al., 2018). What is the potential of available nutrient resources (excreta + synthetic) to help solve the global challenges of reducing nutrient deficits and nutrient 
surpluses? Note, the current global estimates of global crop nutrient need are based on today's yield estimates (Bruinsma, 2011; Tenkorang and Lowenberg-Deboer, 2009; Tilman et al., 2011). These estimates generally do not consider the additional crop nutrient needs that are required to close the crop yield gaps on the lower fertility soils (Sanchez, 2002). Moreover, the current estimates do not consider the contribution of soil nutrients of fertile soils in meeting the crop nutrient need (Hanserud et al., 2015). More work is needed to estimate the potential of excreta to close crop yield gaps, and to minimize the nutrient surpluses by reducing the unnecessary use of synthetic fertilizers.

\subsubsection{Adjusting the recycling strategies at local scales}

Nutrient recycling goals could be different for different nations. The goal could be to improve nutrient supply in order to improve food production or to reduce the nutrient surplus in order to mitigate the problem of nutrient emissions and environmental pollution. For example, in Pakistan, $22 \%$ of the population is undernourished, and the country ranks $77^{\text {th }}$ on the global food security index (EIU, 2014). Crop yields are lower than expected, given the climatic conditions: the current wheat yields in the country are less than half of the expected (Prikhodko and Zrilyi, 2013). Inadequate supply of essential crop nutrients, i.e., N, P, and K, is the leading cause of these yield gaps (Solaiman and Ahmed, 2006). A minor proportion of the livestock and the human excreta are reused in crop production, meaning most of the excreta nutrients are unutilized in the country (FAO, 2004b). For Pakistan, the recycling goal is to find ways to increase the recycling of excreta nutrients to meet the crop nutrient need. In contrast, in Sweden, an increased input of nutrients have been identified as a major source of anthropogenic nutrient load to the Swedish water bodies, and broadly speaking, to the Baltic Sea (Granstedt, 2000; Mccrackin et al., 2018). The recycling goal for Sweden is to eliminate the nutrient surpluses for the sake of environmental health. In summary, spatial nutrient imbalances are highly variable between countries and are linked to different issues. It is important to compare different parts of the world, considering specific recycling objectives in terms of geographic and cultural aspects.

As such, for meeting the global targets of recycling, it is vital to adjust the recycling strategies at national, subnational, and local scales (Häyhä et al., 2016; Kahiluoto et al., 2015). To understand the complete picture of recycling needs, it is necessary to provide quantitative estimates of excreta supply and crop nutrient need at different spatial scales - global, national, subnational, and at local scales. Moreover, it is important to consider the ecological and social facets of nutrient need and supply at the relevant scales. The ecological and social facets of nutrient use at the relevant scales are important to achieve the global targets of sustainable nutrient use (Häyhä et al., 2016).

\subsubsection{Finding ways to minimize the costs of complete excreta recycling in a country}

In order to reuse excreta in crop production, transports over longer distances are often cited as an economically expensive endeavor (Keplinger and Hauck, 2006; Nicholson et al., 2012; Westerman and Bicudo, 2005). Analyzing cost-optimized transports of surplus excreta to the areas of nutrient need is one way to estimate transport distances and associated costs for increased reuse of excreta (Biberacher et al., 2009; Paudel et al., 2009; Ribaudo et al., 2011; Warnecke et al., 2010). However, the nature of the data inputs to the optimization modeling 
could affect the results (Harrison et al., 2010; Horritt and Bates, 2001; Metson et al., 2017). As such, estimating transport needs is a difficult issue, and the previous studies have done very coarse estimates without proper spatial analysis. The method for analyzing need and supply may be scale-dependent so that data input may be a sensitive issue. More detailed modeling of the spatial transport needs is needed to give more realistic estimates of the costs involved in an entire country. 


\subsection{Objectives}

The overall objectives of this thesis were: i) to investigate the potential of excreta to meet the crop nutrient needs at different spatial scales (global to local), and ii) to analyze the need for excreta transports, total distances and costs, to meet the crop nutrient need in a country.

- What is the quantitative potential of global excreta resources to meet the crop nutrient needs to close the crop yield gaps and to decrease the dependency on synthetic fertilizers?

- What is the quantitative potential of excreta to meet crop nutrient need at subnational and national scales in Pakistan and Sweden? What are the transport needs for complete excreta recycling in a country?

- What is the effect of the input data resolution on the results (transport needs and distances) from a model to optimize excreta redistribution in different geographical and cultural contexts? 


\section{Methods}

\subsection{Overview}

In this study, using spatial data on excreta nutrient supply (excreta refer to both human excreta and livestock manure $)^{3}$ and crop nutrient need, we calculated the mass balance ${ }^{4}$ of $\mathrm{N}, \mathrm{P}$, and $\mathrm{K}$ at the national scale across the globe (Paper-I ), at district-scale across Pakistan (Paper-II), at municipal-scale across Sweden (Paper-III), and at 0.083-degree grids across both Sweden and Pakistan, and $5 \mathrm{~km}$ by $5 \mathrm{~km}$ grids across Sweden (Paper-IV). After calculating the nutrient mass balance, we estimated the transports of surplus excreta from surplus areas to the deficit areas to even out the differences between nutrient surplus and deficits, and to meet the crop nutrient need (Papers II, III, and IV). We analyzed the impact of data resolution in calculating the nutrient surpluses and deficits and compared the distances and costs for transporting surplus excreta at these resolutions in Sweden and Pakistan. Finally, we compared the transport costs and possible savings on synthetic nutrients by reusing all excreta in each of the two countries.

\subsection{Spatial resolution}

Most of the data was available at multiple resolutions in Sweden but had to be prepared for a higher resolution for some data in Sweden and all data for Pakistan, especially for Paper-IV (Figure 1). The latter was an essential methodological input of this study because mostly highresolution spatial data was not readily available in developing countries. To prepare the higherresolution data in Pakistan, we combined the lower-resolution spatial data on crops, livestock, and humans given at the district scale with the higher-resolution data given at a grid-scale. Using transformed gridded data (crop, livestock, and humans), we calculated the gridded nutrient balance. More specifically, in Pakistan, the district scale (political resolution) data (crops, livestock, and humans) transformed to decimal degree resolution (0.083 grids). In Sweden, the information of soil nutrient concentration of $\mathrm{P}$ and $\mathrm{K}$, and agroecological regions were combined with the higher resolution crop data. Municipal-scale (political) data for number of livestock and humans were transformed to farm-scale data on number of livestock, and humans at human settlements. Figure (1) gives an overview of the transformation procedure from lower to higher resolution of different types of data in Sweden and Pakistan.

\subsection{Excreta nutrient supply}

Excreta contains large amounts of plant nutrients, which could be used in crop production. For example, $\mathrm{N}$ excretion in livestock excreta was 55 to $80 \%$ of the intake, and $\mathrm{P}$ excretion was 55 to $90 \%$ of the intake, in fodder and feed (Šebek et al., 2014). Almost $100 \%$ of the dietary P intake by a human was excreted (Jonsson et al., 2004). Based on the diet and the body type, nutrient excretion rates per individual were highly variable among different regions and countries. For example, $\mathrm{P}$ excretion rate by a person in China was almost double than the $\mathrm{P}$ excretion rate of a person in Haiti (Jonsson et al., 2004). Similarly, the average excretion rate of cattle, for example, $\mathrm{N}$, in the EU were almost double than the average excretion rates of cattle in Africa (Sheldrick et al., 2003). These excretion rates also differed between different

\footnotetext{
${ }^{3}$ In paper-II we used the term biosupply to refer to both human excreta and livestock manure.

${ }^{4}$ In this thesis, the term nutrient balance is defined as nutrient input minus crop need at a specific scale. Inputs could be excreta only or excreta plus synthetic fertilizers.
} 
categories of livestock species. For example, $\mathrm{N}$ excretion rates for dairy cows were more than double the rates for young dairy stocks and more than triple the rates for other cattle in Asia (Gerber et al., 2005).

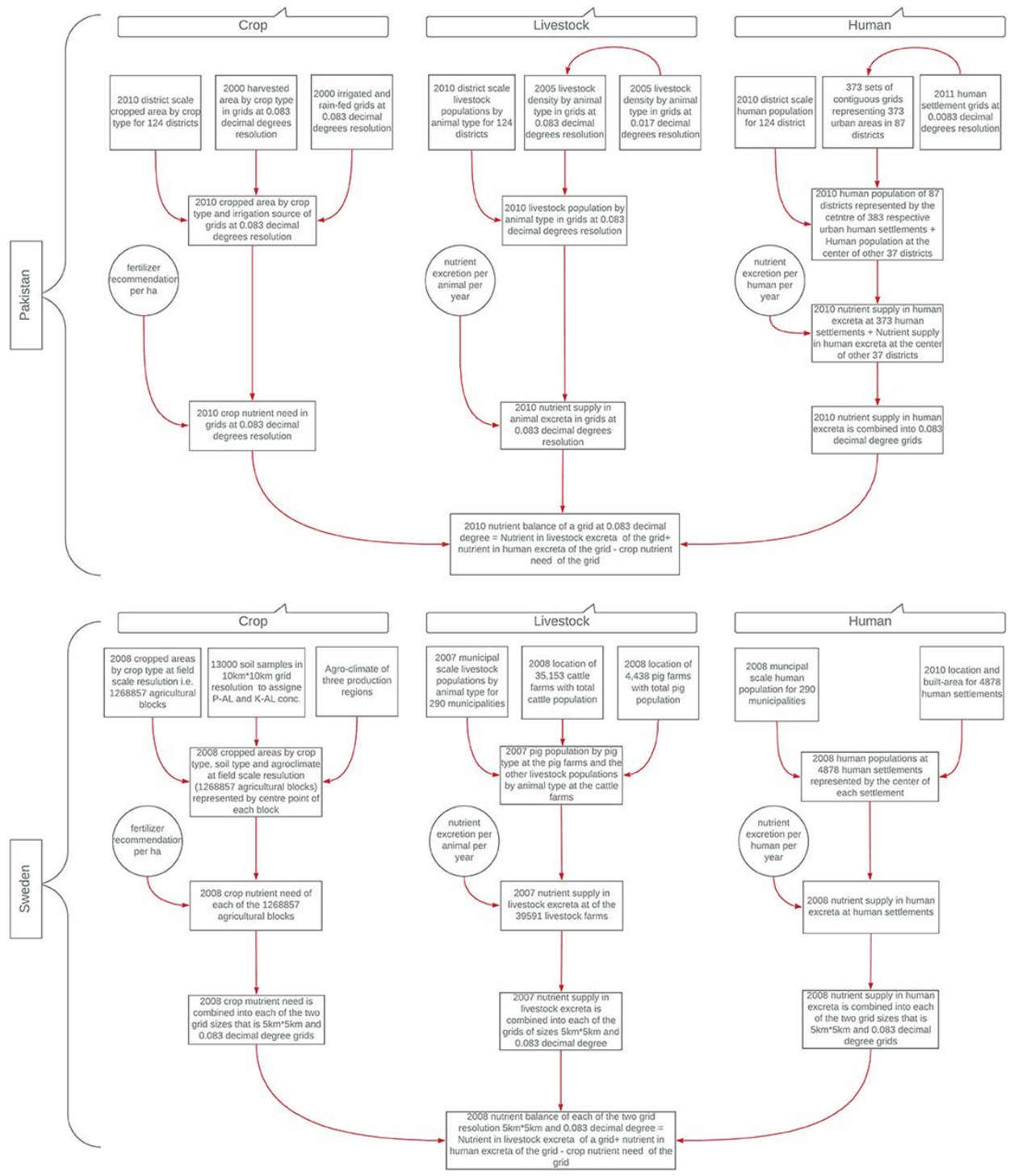

Figure 1. Data transformations from lower to higher resolution used to calculate nutrient balances in grids in Sweden and Pakistan. In Pakistan, the political scale (district) data for crops, livestock, and humans were converted to 0.083 decimal degree grids. In Sweden, the higher resolution crop data were transformed to include information of soil type and production region, and political scale (municipal) data for livestock and human were converted to farm livestock type and numbers, and human population to human settlement locations. All these datasets were then converted into crop nutrient needs and excreta nutrient supply and then into the gridded nutrient balances in each country. The figure is adapted from (Akram et al., 2019) 
In order to calculate the amount of nutrients in excreta, we combined (multiplied) the information of number of individuals of livestock type and human populations (at the respective scales/resolutions) with their respective excretion rates. We excluded the amount of excreta nutrients lost as gas during storage and field application (Paper-I to IV) and amount of the excreta of rangeland livestock populations from the total supply (Paper-I). In this respect, we combined several data sets. For more details of the scales/resolutions and sources of data used to quantify the amount of nutrients (and losses) in excreta, see Table (1).

\subsubsection{Losses from excreta}

Ammonia $\left(\mathrm{NH}_{3}-\mathrm{N}\right)$ losses could occur during the storage and handling of excreta. $\mathrm{NH}_{4}{ }^{+}$ions could form by the microbial hydrolysis of urea and uric acid, and the action of enzyme urease present in the excreta. The $\mathrm{NH}_{4}{ }^{+}$ions could easily convert to $\mathrm{NH}_{3}-\mathrm{N}$ gas and thus lead to the loss of $\mathrm{NH}_{3}-\mathrm{N}$ from excreta. An increase in excreta $\mathrm{pH}$ and temperature could increase the ratio of dissolved $\mathrm{NH}_{3}-\mathrm{N}$ to total ammoniacal- $\mathrm{N}\left(\mathrm{NH}_{3}+\mathrm{NH}_{4}\right)$ in excreta. The dissolved $\mathrm{NH}_{3}-\mathrm{N}$ could be lost from the stored excreta to the environment through volatilization because $\mathrm{NH}_{3}-\mathrm{N}$ has lower partial pressure in the air than in the excreta.

The excreta from different animal species could have different $\mathrm{pH}$ values (Dai and Karring, 2014). Moreover, there are substantial regional differences in temperature. Thus $\mathrm{NH}_{3}-\mathrm{N}$ loss from excreta could be different for different regions and animal species (Bouwman et al., 1997). Most of the recent studies that included $\mathrm{NH}_{3}-\mathrm{N}$ emission from excreta used the loss factors developed by Bouwman et al., (1997), for example, in Bouwman et al., (2013) and Liu et al., (2010). These factors were given by regions, i.e., different countries were grouped into different regions with their specific emission factor. In contrast, we used country-specific factors of total volatile losses of $\mathrm{N}$ during storage of excreta, which we obtained from FAOSTAT (2019a).

Upon spreading, excreta supply both organic- $\mathrm{N}$ and inorganic-N to the soil. Plants could readily take up the inorganic form. However, organic-N first needs to be transformed in the soil to ammonium through mineralization before the plants could utilize it. Urease is usually active in the soil and breaks the residual urea and other $\mathrm{N}$ compounds. As discussed above, $\mathrm{NH}_{4}{ }^{+}$could readily transform to $\mathrm{NH}_{3}$ at higher $\mathrm{pH}$ and thus subject to volatilization losses. It is, therefore, needed to be immediately incorporated into the soil. Nitrate $\left(\mathrm{NO}_{3}{ }^{-}\right)$is another inorganic form of $\mathrm{N}$ in excreta. It is readily available to plants. However, it is usually only found in negligible amounts in excreta. Other than gaseous, and field application losses, there are considerable recovery losses in excreta. For example, only 17 to $19 \%$ of the global $\mathrm{N}$ produced in the livestock excreta was applied to the cropland (Zhang et al., 2017). Most of the non-gaseous losses came from uncollected excreta and excreta used as fuel or building material (Bouwman et al., 2013; Sheldrick et al., 2003). It is important to note that the excreta spread during animals were grazing might be reused in the regrowth of the grass and herbs in the grasslands. However, the amount of excreta dropped during grazing might not match the nutrient need of the grasslands. The excreta could supply more, or even fewer nutrients compared to the actual nutrient need of the grazing lands. There are also nutrient losses from human excreta. A recent estimate suggested that only a minor proportion, i.e., $11 \%$ of the $\mathrm{N}$ and $\mathrm{P}$ in the wastewater, was recovered during the wastewater treatment process at the global scale (van Puijenbroek et 
al., 2019). Most of the nutrients in the wastewater were lost either to the atmosphere or the global waters. Notably, the differences in nutrient recovery for different nations were massive.

Table 1. Primary data sources used to estimate the crop nutrient need and excreta nutrient supply in different Papers.

\begin{tabular}{|c|c|}
\hline Paper & Excreta nutrient \\
\hline I & $\begin{array}{l}\text { Country scale data on the total number of livestock by livestock type were obtained from } \\
\text { the FAOSTAT database (FAOSTAT, 2019b) } \\
\text { In order to calculate nutrient excretion rate by animal type and country we combined } \\
\text { three data sets: } \\
\text { 1. Country scale data on the N excretion rates per unit of animal mass by livestock } \\
\text { type (FAOSTAT, 2019c) } \\
\text { 2. Country scale data on the typical animal mass by animal type (FAOSTAT, 2019d) } \\
\text { 3. The ratio of P and K over N excretion by livestock type (Sheldrick et al., 2003) } \\
\text { We estimated the unavoidable nutrient losses during storage of excreta using gaseous loss } \\
\text { emission factor by animal excreta type and country (FAOSTAT, 2019a). } \\
\text { We estimated uncollectable nutrient excretions of the rangelands by country and animal } \\
\text { type using three data sets (FAOSTAT, 2019b; Gilbert et al., 2018b, 2018c, 2018d, 2018e, } \\
2018 f, 2018 \mathrm{~g}, 2018 \mathrm{a} \text {; Robinson et al., 2018). } \\
\text { Country scale data on the human population were obtained from (FAOSTAT, 2019e). } \\
\text { In order to calculate human excretion rate by a country we used the procedure described } \\
\text { by Jonsson et al., (2004) and the data on total protein supply per person per day in a } \\
\text { country (obtained from FAOSTAT, (2019f)). } \\
\text { We estimated storage losses of nutrient from human excreta using the loss factors given } \\
\text { by Eklind and Kirchmann (2000), Jönsson et al. (2003) and (2000), and Trémolières et } \\
\text { al. (1961). }\end{array}$ \\
\hline II & $\begin{array}{l}\text { District-scale data on livestock population were obtained from PBS (2012) and (2006). } \\
\text { Data on livestock excretion rates were obtained from Gerber et al. (2005) } \\
\text { District-scale data on the human population was obtained from BOS }(2014,2013,2011 \text {, } \\
\text { 2010) } \\
\text { Data on human excretion rates were obtained from Jönsson and Vinnerås, (2004) } \\
\text { We estimated the gaseous loss of excreta nutrients during storage using the gaseous loss } \\
\text { factor obtained from Bouwman et al. (1997). }\end{array}$ \\
\hline III & $\begin{array}{l}\text { Municipal-scale data on livestock populations were obtained from Statistics Sweden } \\
\text { (2008). } \\
\text { Data on livestock excretion rates were obtained from Albertsson, (2007) and CBS (2012). } \\
\text { Municipal-scale data on human populations were obtained from Statistics Sweden } \\
\text { (2017). } \\
\text { Data on human excretion rates were obtained from Jönsson and Vinnerås (2004). } \\
\text { We estimated the gaseous loss of excreta nutrients during storage using the gaseous loss } \\
\text { factor obtained from Jakobsson and Steineck (2012). }\end{array}$ \\
\hline IV & $\begin{array}{l}\text { For Sweden, we converted low-resolution municipal-scale livestock population data } \\
\text { (used in Paper-III) to farm level livestock population (JBV, 2018a). } \\
\text { For Sweden, we converted low-resolution municipal scale human population data (used } \\
\text { in Paper-III) to high-resolution human population at human settlement data (SCB, 2010). } \\
\text { For Pakistan, we converted low-resolution district-scale data (used in Paper-II) to high } \\
\text { resolution gridded (Robinson and Conchedda, 2011; Robinson et al., 2014). } \\
\text { For Pakistan, we converted low-resolution district human population data (used in Paper- } \\
\text { II) to high-resolution human population at human settlements data (Robinson and } \\
\text { Conchedda, 2011). } \\
\text { We estimated the gaseous loss of excreta nutrients during storage using the gaseous loss } \\
\text { factor obtained from Bouwman et al. (1997) for both countries. } \\
\text { The data on the excretions rates were obtained from the same sources as in Paper-II and } \\
\text { Paper-III for the respective countries. }\end{array}$ \\
\hline
\end{tabular}

Crop need calculation

Country scale data on harvested crop areas were obtained from FAO/IIASA (2010), and FAOSTAT $(2019 \mathrm{~g})$

We compiled the fertilizer recommendation for the countries, which contributed to the top $70 \%$ of the global harvested area each of each crop. There were 91 countries, which contributed to at least the top $70 \%$ or more of the global harvested area of each crop. See the complete list of fertilizer recommendation by crop and country in SI material for Paper-I.

Data on total district cropped area by crop type were obtained from PBS (2012).

Data on fertilizer recommendation by region were obtained from Ashiq (2010) and FAO (2004b).

Municipal-scale data on crop areas by crop type were obtained from Statistics Sweden (2011).

Data on soil nutrient concentration were obtained from Swedish Board of Agriculture (2017).

Data on the agroclimatic region were obtained from Ericsson (1988).

Data on fertilizer recommendation by soil type and the agroclimatic region were obtained from Albertsson (2007).

We obtained the Swedish high-resolution data on crop area by crop type in the agricultural blocks from JBV, (2018b).

We used the same data source of the agroclimatic region and soil nutrien concentration as in Paper-III.

For Pakistan, we converted low-resolution district data (used in Paper-II) to highresolution gridded data using (FAO/IIASA 2010).

The data on the fertilizer recommendations were obtained from the same sources as in Paper-II and Paper-III for the respective countries.

Most of the studies today accounted for the total amount of nutrients in excreta when estimating the excreta potential for reuse in crop production and in calculating nutrient balance (OECD \& Eurostat, 2007). However, the method of excreta collection and storage processes might have a considerable impact on nutrient losses. Moreover, a considerable amount of nutrients was not 
readily available to crops during the first year of application. That was mostly because the nutrients shift forms into different compounds in the soil over time, and plants were only able to use some of these nutrients (Wilson, 2018). In other words, in the mineralization process, microbes transform organic nutrients into inorganic forms, and this process could take several years, depending on soil and excreta characteristics. In this respect, the method of excreta application might also affect the plant availability of nutrients for a given time. For example, in Sweden, it was required by law to incorporate the excreta into the soil within 12 hours of field application (Nilsson, 2013). In this respect, in Sweden, over 55\% N in excreta, $80 \%$ of excreta $\mathrm{P}$, and $90 \%$ of excreta $\mathrm{K}$ (depending on the excreta type) could become crop available in the first year of its application (Wilson 2018).

\subsection{Crop nutrient need}

Most of the current global estimates of crop nutrient need were based either on food consumption (Bruinsma, 2011), known relationships between crop nutrient use and gross domestic product (Tilman et al., 2011), or relationships between application rates and the crop output (Tenkorang and Lowenberg-Deboer, 2009). However, such approaches seem inaccurate, considering the need to close nutrient-related crop yield gaps. Because they were based on statistics and might contain data that belongs to crop fields that had have not received enough fertilizers. Estimating crop nutrient need at the current yields discounted the chances of improving the crop yield. Sanchez (2002) argued that in areas losing fertility, the crop nutrient needs assessments should include the fertilizers needed to bring the agricultural land back to fertility levels. Moreover, the existing approaches ignored the nutrient reserves of the soils that were overapplied in the past. These soil nutrients could contribute to improving crop yields. For example, in Sweden, there were seven types of soil based on the P concentration and five types of soil based on the K concentration (Swedish Board of Agriculture and JBV, 2017). Fertilizer recommendations for different soils were profoundly different. For example, for winter wheat, for the soils with the highest $\mathrm{P}$ concentration, the recommendation for $\mathrm{P}$ was zero, while for the soils with the lowest $\mathrm{P}$ concentration in the country it was $38 \mathrm{~kg}$ per ha (Albertsson, 2007).

We believed that the existing approaches were not appropriate for estimating the crop nutrient need to harvest higher crop yields. Those approaches did not reflect the efficient use of the available soil nutrients. For example, we might need to apply less nutrients than what was expected in the crop harvest from fertile soils or soils which were heavily fertilized in the past. More recent studies had started to estimate the crop nutrient need based on fertilizer recommendation, for example, Trimmer and Guest, (2018). Trimmer and Guest, (2018), used a median value of fertilizer recommendations for a crop grown in different countries and estimated the global crop nutrient need. Considering the effect of substantial regional differences in climate and soils, we decided to use more specific fertilizer recommendations. More specifically, we used country-specific fertilizer recommendations at the global scale (Paper-I) and region-specific in Sweden and Pakistan (Papers II, III, and IV). We assumed that the fertilizer recommendation values were prepared according to local climatic and soil conditions in order to harvest the highest possible yields. 


\subsection{Nutrient balance}

Himmeblau (1967) first described the mass balance approach, which compared the magnitude of input vs. the output of a material in a system or a process. The mass balance approach had been used to calculate nutrient balance at different scales (Bindraban et al., 2000; Granstedt et al., 2004; MacDonald et al., 2012; Metson et al., 2016). Estimating nutrient balance as surplus and as deficits had different objectives. For example, a nutrient balance was an indicator of environmental loads of nutrients (if surplus), and of the soil nutrient depletion (if deficit). In more recent studies, a nutrient balance had been used as an indicator of spatial separation of crop and animal production. Similarly, the objective of this study was to use the mass balance approach to estimate the spatial separation of crop nutrient needs and excreta nutrient supply. We used excreta nutrient supply as input and crop nutrient need as output to calculate the nutrient balance of $\mathrm{N}, \mathrm{P}$, and $\mathrm{K}$ at multiple spatial resolutions, simultaneously. We excluded the excreta nutrient losses as gas in all Papers and uncollectable excreta of the rangeland in Paper(I). We adjusted crop nutrient needs to soil types in Paper (III) and (IV) and source of irrigation in the paper (IV). In Pakistan, fertilizer recommendations were usually also based upon the prevailing source of water for crop production (FAO, 2004b).

The nutrient balance had been calculated at different spatial resolutions across the globe. At lower spatial resolution, for example, at county scale in Norway (Hanserud et al., 2015), at a regional scale in France (Senthilkumar et al., 2012), and England (Bateman et al., 2011). The lower spatial data resolution provided fewer details of an area than the higher spatial data resolution. More recent studies had calculated nutrient balance at a more detailed spatial resolution, for example, at parish scale in Denmark (Parchomenko and Borsky, 2018) and a grid of $2 \mathrm{~km} * 2 \mathrm{~km}$ in Scotland (Leinonen et al., 2019). These studies calculated nutrient balance at a single resolution - regardless of whether it was a low or a high-resolution nutrient balance. As it would be interesting to see the impact of data resolution on nutrient balance, we did the calculations at multiple resolutions in this study.

\subsection{Redistribution of excreta}

Excreta transport optimization was not a new concept; it had been used in many other studies (Biberacher et al., 2009; Paudel et al., 2009; Ribaudo et al., 2011; Warnecke et al., 2010). Its purpose was to minimize cost and to increase transport efficiency. Input parameters and/or variables to the excreta optimization model were different in the different studies. For example, Paudel et al. (2009) used an excreta transportation model aimed at minimizing the transports costs between dairy farms and croplands. The input they used in the model included the land use types, animal farm locations, cropland, road networks, and distances between the cropland and the animal farms. Biberacher et al. (2009) used the linear optimization model to minimize the transportation cost of the surplus excreta nutrient between the surplus and the deficit districts. The authors had put two restrictions to the optimization model. 1) maximum allowed animal excreta application was $170 \mathrm{~kg} \mathrm{~N}$ per ha. 2) maximum allowed animal excreta application was $80 \%$ of the $\mathrm{N}$ and $\mathrm{P}$ crop need. Ribaudo et al. (2003) designed the optimization model to minimize animal excreta transport costs within and between the counties. There model included even stricter constraints than the other studies, for example, not only hauling, but the land application, incorporation, and nutrient management costs were also included, and even a 
penalty-cost was excluded if the animal excreta application exceeded the land application. In this study, we used a similar optimization approach but with a different set of constraints and parameters at different spatial scales in a country. In other words, we moved from a specific region or area in a country to the whole country level. For example, the input data in our optimization model ensure that all excreta nutrients in a country were used to meet the crop nutrient need. We estimated the total distances and costs in a country.

In this thesis, excreta optimization model had two types of use: i) pre-balanced, ii) non-prebalanced. In the pre-balanced scenario, we pre-balanced nutrient need and supply at the respective spatial scales, i.e., municipal scale in Sweden and district-scale in Pakistan, and at the gridded scale in Sweden and Pakistan. After pre-balancing, we decided on the nutrient to run the transport optimization. We decided to run the excreta $\mathrm{P}$ optimization in case of Sweden and excreta N optimization in case of Pakistan (See Paper II and Paper III for specific motives). In non-pre-balanced, we did not pre-balance the crop need, and the excreta supply and model itself balanced the crop need and excreta supply simultaneously for N, P, and K (See Paper-III, for more details).

\subsection{Economic benefit of the nutrients reuse}

Biberacher et al. (2009) argued that a regional analysis of the reuse of excreta could make it possible to analyze the substitution of the expensive synthetic fertilizers. In other words, increased reuse of excreta could compensate for the use of synthetic fertilizers, resulting in a saving on synthetic nutrients. The savings on synthetic fertilizers were comparable to the costs of excreta transports. For example, Ribaudo et al. (2003) showed that potential savings on synthetic fertilizers, with the reuse of excreta, could contribute 40 to $55 \%$ of the total cost of reusing excreta to meet the crop need.

Several factors could affect the estimates of economic benefit of reusing excreta nutrients: for example, transformation of Euclidean distance into actual road distance, monetary value of the excreta nutrients, and the transportation cost of excreta. We used a 1.33 factor to approximately transform the Euclidean distance into actual road distance (Gonçalves et al., 2014). The factor 1.33 was in the middle of the national and international values, which was 1.1 to 1.5 (Nilsson, 2010; Sultana and Kumar, 2014). We used the transport cost of 0.02\$/ton-km for Pakistan (Teravaninthorn and Raballand, 2008), and 0.25\$/ton-km in Sweden (Greppa Näringen, 2012). The transport cost value we used for Sweden was in the middle of the national and international estimates (Evans et al., 2014; Olsson et al., 2014). For Pakistan, we calculated the synthetic nutrient value using synthetic fertilizers' sales data from National Fertilizer Development Center (NFDC, 2010). For Sweden, we obtained the value of $1 \mathrm{~kg}$ of a nutrient from (Greppa Näringen, 2008).

The economic feasibility of excreta transports could also be analyzed by estimating the costs of the excreta transports and the value of the excreta nutrient transported. Using these values, we compared the costs of savings on synthetic fertilizers with transport costs. We showed the effect of reusing excreta on reducing the use of synthetic nutrients at a national scale in a country, which was lacking in the previous work. With an increasing transport distance, transportation costs increase. In previous studies, a standard indicator of economic viability was the maximum distance over which excreta could be transported considering the excreta value. The pricing of 
excreta was usually based on a single nutrient. Paudel et al. (2009a) estimated a breakeven point for excreta $\mathrm{N}$ transport of $30 \mathrm{~km}$, and for excreta $\mathrm{P}$ and $\mathrm{K}, 15 \mathrm{~km}$. In other words, considering excreta $\mathrm{N}$ transport costs and excreta $\mathrm{N}$ value, it was cheaper to use excreta $\mathrm{N}$ within $30 \mathrm{~km}$ of transport distance. Over $30 \mathrm{~km}$, it would be cheaper to use synthetic N. To decide between excreta $\mathrm{P}$ and $\mathrm{K}$ and synthetic $\mathrm{P}$ and $\mathrm{K}$, this distance was $15 \mathrm{~km}$. Contrary to previous studies that compared the value of one nutrient to estimate the cost-benefit of that nutrient, we included the value of all three nutrients. Note, we discounted the value of the nutrients that ended up in the wrong place, i.e., that did not provide the crop nutrient need. 


\section{Results}

\subsection{Paper-I}

By estimating crop nutrient need at potential crop yields and the nutrient supply (excreta + synthetic), Paper-I aimed to assess the potential of available nutrient resources to meet the crop nutrient needs across the globe. These estimates were produced on annual data from 2000 to 2016, and we compared the nutrient need and supply trends over time. The annual total global crop nutrient need ranged between 140 to 163 million tons of N, 36 to 43 million tons of $\mathrm{P}$, and 82 to 98 million tons of K (Paper-I, Figure 1). The annual total global excreta supply ranged between 69 to 80,21 to 25 , and 71 to 81 million tons of $\mathrm{N}, \mathrm{P}$, and $\mathrm{K}$, respectively. The excreta had a considerable potential to meet the crop nutrient needs. However, there were vast differences between countries. For example, at least 29,41 , and 71 countries had an oversupply of excreta for N, P, and K, respectively (Paper-I: SI Table 4). Including the use of synthetic fertilizers, annually, at least 42,17 , and 8 countries, additional to the excreta surplus, attained an oversupply of N, P, and K, respectively (Paper-I: SI Table 5). Many countries had an undersupply of nutrients compared to their crop needs, even after including the use of synthetic fertilizers. Annually, at least 57, 70, and 51 countries had an undersupply of N, P, and K, respectively. Using the annual nutrient balances, we classified the countries into four distinct groups: 1) increasing surplus, 2) decreasing surplus, 3) decreasing deficit, 4) increasing deficit. The annual total deficit in the groups having an undersupply was at least $14 \%$ and $16 \%$ of the global N, and P, K crop needs, respectively (Paper-I: Figure 4). On the other hand, the total annual surplus was at least $40 \%, 43 \%$, and $100 \%$ of the global use of synthetic $\mathrm{N}, \mathrm{P}$, and $\mathrm{K}$, respectively. The nutrient deficits in the deficit groups and nutrient surplus in the surplus groups are increasing over time (Paper-1: Figure 4). These nutrient imbalances across the globe suggest the need for redistribution of nutrients within and among the countries. Such redistribution would have a considerable impact on closing the global crop yield gaps, and on reducing the surplus use of synthetic fertilizers.

\subsection{Paper-II}

Using the spatial data on crop nutrient need and excreta nutrient supply at the district scale across the country, and national scale data on actual synthetic fertilizer use, Paper-II aimed to estimate the quantitative and logistic potential for excreta nutrient recycling across Pakistan. Results showed that synthetic fertilizer use combined with poor recycling of excreta resulted in a large gap between P and K supply and the crop nutrient need (Paper-II: Table 4). An additional USD 3 billion is required to fill the gap with synthetic fertilizers. If all excreta were recycled, the need for synthetic $\mathrm{K}$ could be eliminated, and the need for synthetic $\mathrm{N}$ could be reduced to $43 \%$ of the current purchase, but the country would still need .28 million tons of synthetic $\mathrm{P}$ to meet the crop P need (Paper-II: Figure 2). The additional need for synthetic nutrients would cost USD 2.77 billion (Paper-II: Table 4). Pakistan already spend this money on synthetic fertilizers - but mostly on N (Paper-II: Table 2). If some of the money, used on the purchase of synthetic $\mathrm{N}$ were reallocated to purchase synthetic $\mathrm{P}$, it might not be excessively expensive to meet the $\mathrm{P}$ crop needs in the country. Most of the crop nutrient need and excreta nutrient supply were co-located at the district scale in-country (Paper-II: Figure 3, Table 5). More specifically, most of the recycling of excreta would be within districts; only $6 \%$ of the excreta supply would 
need to be transported between districts. Recycling all excreta and adjusting the use of synthetic fertilizers to offset the gap between crop nutrient need and excreta nutrient supply would promote a balanced crop nutrition (appropriate ration of $\mathrm{N}, \mathrm{P}$, and $\mathrm{K}$ use) in the country. Increased excreta recycling, promoting a balanced application of $\mathrm{N}, \mathrm{P}$, and $\mathrm{K}$ would be a way to decrease the nutrient-related crop yield gaps in Pakistan.

\subsection{Paper-III}

In this study, we explored the logistical options and transport costs associated with an enhanced reuse of excreta in a country with a national nutrient excess. To do this, we estimated the spatially explicit nutrient budgets at municipal-scale in Sweden and used these nutrient budgets to explore the transportation and logistical options among different municipalities for an enhanced reuse of excreta across the country. The results showed that excreta could provide most of the country's crop nutrient need, i.e., up to $75 \%$ of $\mathrm{N}$ and $81 \%$ of $\mathrm{P}$, but this would result in an oversupply of $\mathrm{K}$ by $67 \%$ (Paper-III: Figure 1). However, there were substantial regional differences and imbalances of nutrient need and supply across the country (Paper-III: Figure 2, Table 1). For example, just $40 \%$ of the municipalities had over $50 \%$ of the total national scale supply of excreta $\mathrm{N}$ and $\mathrm{P}$ (Paper-III: Table 2). These municipalities had a surplus of excreta nutrients compared to the crop needs, and such imbalances needed to be corrected for complete reuse of excreta in crop production. Most of the recycling of excreta could take place within municipalities, i.e., 63\% of the national P crop need (Paper-III: Figure 3). The rest of the excreta would need to be transported out of the surplus municipalities. Nationally, when optimizing for $\mathrm{P}$, the reallocation of excreta surplus from surplus municipalities towards the deficit municipalities showed that 193 municipalities would get a balanced excreta P supply and P crop needs (Paper-III: SI Table 13). Such redistribution of surplus excreta would cost USD 192 million annually and cover a total distance of 24,079 km of truck travel in Sweden (Paper-III: SI Table 12). The transportation cost was 3.7 times higher than the fertilizer market value of the total NPK transported in the surplus excreta. The results showed that Sweden could replace most of its dependence on synthetic fertilizers with investments aimed at enhancing the reuse of excreta nutrients. However, these investments for excreta transports would likely require valuing also benefits other than recycling.

\subsection{Paper-IV}

Paper-IV aimed to analyze how sensitive the results of an excreta recycling optimization model were to the nature of the input data, using Sweden and Pakistan as examples. The Paper analyzed the effect of the nature of the data in two contexts, i.e., comparing the spatial data input from the two countries, and comparing the spatial data input at multiple resolutions in each of the two countries. More specifically, the Paper analyzed: 1) the amount of excreta that needed transport, 2) the distances required to transport surplus excreta and the patterns of transport, 3) the cost associated with transporting surplus excreta, and 4) potential savings on synthetic fertilizers. 


\section{Pakistan}

A. Transport requirements

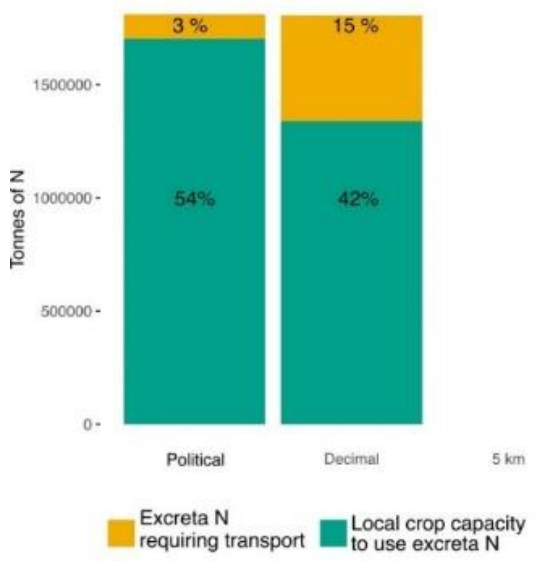

B. Distance distribution

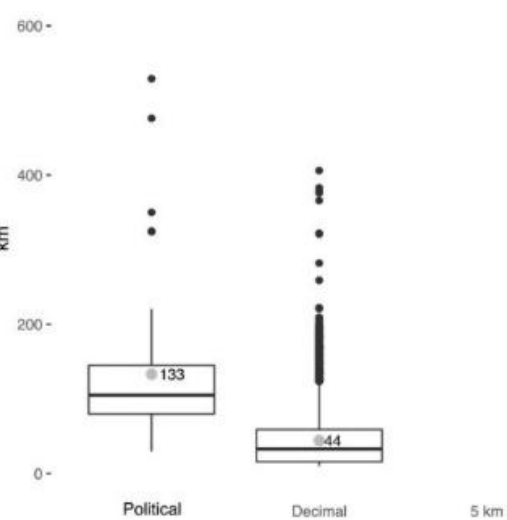

\section{Sweden}
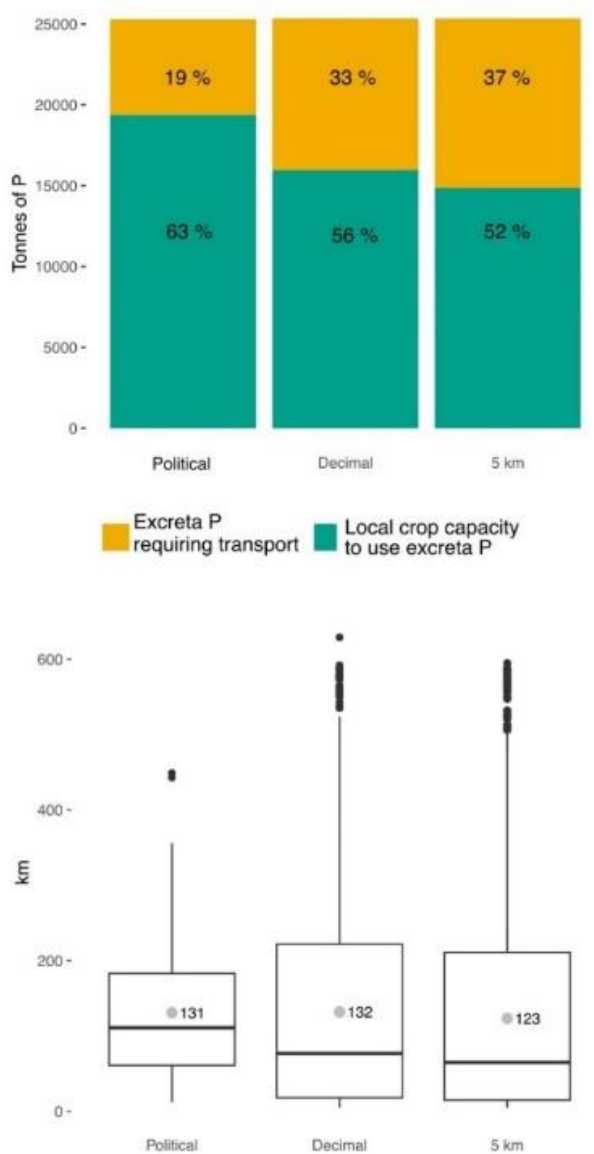

C. Patterns of transport
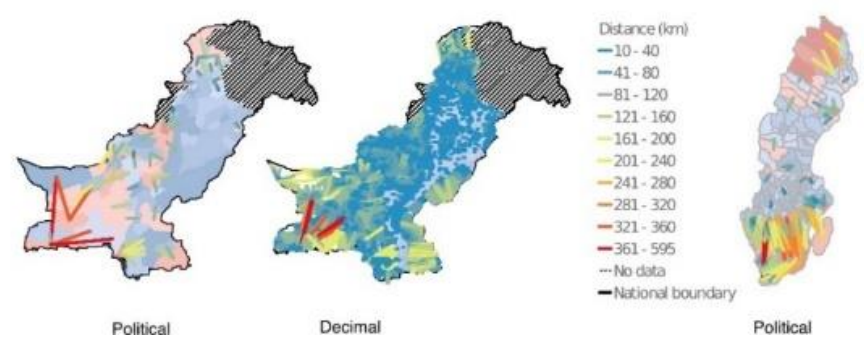

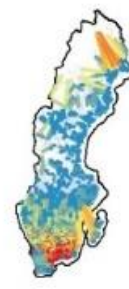

Decimal

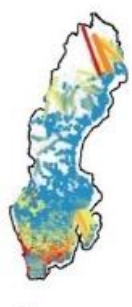

$5 \mathrm{~km}$

Figure 2: Effects of increasing resolution from political, to decimal, to $5 \mathrm{~km}$ scales on the transportation of surplus nutrients in terms of (A) the amount and percentage of the nutrient of interest ( $\mathrm{N}$ for Pakistan and $\mathrm{P}$ for Sweden) requiring transport, (B) the spread of transport distances represented as mean (gray circles and stated value), median (centerline), interquartile range (box representing $50 \%$ of the data), 1.5 times the interquartile range (whiskers), and outliers (black circles), and (C) the paths and distances of transportation on the landscape from surplus (light red) to deficit areas (light blue) color-coded from shorter (blue lines) to longer (red lines). The figure is adapted from (Akram et al., 2019) 
Generally, the results showed that Sweden has more apparent spatial separation of crop nutrient need and excreta nutrient supply at all resolutions, compared to Pakistan (Figure 2). An increase in the spatial data resolution from political boundaries (municipalities in Sweden and districts in Pakistan) to 0.083 decimal degree led to an increase in the amount of excreta nutrients requiring transport in both countries, i.e., 14\% for $\mathrm{P}$ in Sweden, and 12\% for $\mathrm{N}$ in Pakistan. We observed a considerable decrease in the average distance in Pakistan, i.e., 67\% (to $44 \mathrm{~km}$ ). However, in Sweden, the average distance increased by $1 \mathrm{~km}$. Increasing spatial resolution to $5 \mathrm{~km}$ grids in Sweden resulted in a $9 \mathrm{~km}$ (down to $123 \mathrm{~km}$ ) decrease in the average distance of surplus excreta transports. Increasing input data resolution in both countries resulted in a reduced number of long-distance excreta transports; as such, although the total distance and weight transported increased, the transport cost did not increase proportionally. For Pakistan, transporting surplus excreta proved more beneficial than for Sweden: the surplus excreta transportation cost was only $13 \%$ of the market value of the NPK transported (Paper-IV: Table 3 , Figure 4). The savings estimates on synthetic $\mathrm{N}$, with complete recycling of excreta, are more certain in this paper compared to Paper-II. The savings could compensate $78 \%$ additional purchases of $\mathrm{P}$ and $\mathrm{K}$ required to meet the crop nutrient need in the country (Paper-IV: Table 4). For Sweden, even at the highest spatial data resolution, i.e., $5 \mathrm{~km}$ grids, the cost of transporting excreta was slightly higher than three times than the market value of the transported NPK in excreta. The cost to fertilizer value ratios seems more favorable at high resolution (Paper-IV: Figure 4). The results of this Paper showed that an increase in the input data resolution has an impact on creating a realistic view of the recycling needs of surplus excreta and could support actual decisions on investments or policies to enhance productive recycling of excreta nutrients in Sweden and Pakistan. 


\section{Discussion}

4.1 Global dilemma of reducing nutrient flows vs. meeting human food needs

Ever-increasing nutrient input to agriculture, causing surpluses, is one of the primary drivers of water pollution across the globe. Ever-increasing nutrient emissions to waters have shifted the state of many water bodies from clear to turbid waters (Carpenter, 2003; Zillén et al., 2008). Mohajan (2015) argues that the nutrient input must not cross the safety limits defined for the planet (Rockström et al., 2009). In other words, the nutrient input into the marine ecosystems needs to be reduced. Currently, reaching the safe operating space for $\mathrm{N}$ requires a reduction of almost 3.5 times in today's influx into the earth's systems (Rockström et al., 2009). However, such a reduction in nutrient flows may compromise global food supplies. In terms of food supplies, the consequence of reduced nutrient input is huge. For example, Kahiluoto et al. (2014) argue that complying with the required reduction in the $\mathrm{N}$ and $\mathrm{P}$ flows at the planetary scale would cause a reduction of food supply to 250 and $710 \mathrm{kcal}$ per capita per day, respectively. Already, globally, one in eight humans lacks sufficient food supplies (SOFI, 2005; $\mathrm{UN}, 2006$ ). Moreover, due to increasing human population, global food demand is continuously rising. Estimates show that a $70 \%$ increase in food production by 2050 is required to meet the food demand (FAO, 2009b). Meeting the current and future food supplies is a global priority (UN, 2000; IFPRI, 2002b). Closing crop yield gaps is deemed to increase the food supplies in many regions of the globe (Pradhan et al., 2015). However, closing crop yield gaps require, among others, increased nutrient input (Mueller et al., 2012; Pradhan et al., 2015). As such, increased food production would need increased use of fertilizer nutrients (FAO, 2017).

Withers et al., (2015b) argues that human food demand is the primary driver of nutrient need in the food production system. In other words, assessing human food needs should be the first step in estimating the nutrient need in a resource-efficient food production system (Withers et al., 2015b). In terms of the maximum allowed nutrient flows at the planetary scale, this puts an interesting question: what is the safe operating space regarding nutrient input in terms of meeting the global food demands? We tried to estimate that by calculating crop nutrient needs at potential crop yields. Closing crop yield gaps could help in meeting food demands in many hunger-affected areas. Our results show that crop nutrient need at potential crop yields is much higher than the current safe operating space limits defined in the planetary boundary studies (Carpenter and Bennett, 2011; De Vries et al., 2013; Rockström et al., 2009; Steffen et al., 2015). For example, comparing our estimates of global crop N need (Paper-I: Figure 1) with the N limits defined by De Vries et al., (2013) and Steffen et al., (2015), shows that the required $\mathrm{N}$ input is three times higher than the $\mathrm{N}$ use limits defined by these studies. Depending on crop production activity, which varies greatly between nations, the defined nutrient use limits and targets are also different for different nations. For example, our estimates of the required input of $\mathrm{N}$ to meet the crop nutrient need at potential crop yields in China and India is 10 million tons higher than the global N input limit defined by Rockström et al. (2009b).

In summary, considering the global challenges of food supplies, it seems less likely to reach the required reduction in the nutrient flows at the planetary scale. In fact, in many areas, we need to increase the nutrient input to increase food production. As such, the global boundary estimate and concept is not so useful as a basis for action, and that a higher resolution is needed to define 
actual boundaries for continents or countries. Such boundaries need to be coupled with the targets of achieving sustainable societies (Rockström et al., 2009; Steffen et al., 2015; Steffen and Stafford Smith, 2013). In other words, we need to adjust the boundaries not only to meet the safe operating space in terms of environmental issues but also to meet the safe operating space in terms of food demands. To reach these targets, we either need to reduce the nutrient need for food production or enable a large-scale redistribution of the use of nutrients in agriculture.

\subsubsection{Reducing nutrient need by changing dietary habits}

Most of today's need for increasing nutrient input to agriculture relates to dietary habits. Animal production requires more nutrient input to supply an equal amount of protein as from a vegetal source. A significant part of the main crops is used for animal production (Eisler et al., 2014). Dietary choices, in particular the ratio of animal-based food to plant-based food, have an enormous impact on driving the nutrient flows in a system (Metson et al., 2016a, 2012), the efficiency of nutrient use, and environmental impacts (Clark and Tilman, 2017). Therefore, a dietary shift is one of the measures required to reduce nutrient surpluses and subsequent losses (Kahiluoto et al., 2014). Replacing animal-based diets with plant-based diets could lower the nutrient demand in the food production system, and thus the losses. Thaler et al. (2015) found that reducing the current meat diet to $40 \%$ in Austria could reduce the need for $\mathrm{P}$ in food production by 20 to $25 \%$ and that $P$ losses to waters could be reduced by 5 to $6 \%$. However, the goal of reducing animal production is challenging for many reasons. For example, animal production on marginal and unproductive lands contributes to local food security (WSPA, 2012), has a vital role in the livelihood of rural communities (Ellis and Freeman, 2004). In addition, animal production is vital to provide consumers with their much desired dietary choices. These challenges make it difficult to implement transformative changes in the human diet (Withers et al., 2018). Tilman and Clark (2014) argued that increasing wealth in many of the developing nations, along with urbanization and expanding populations, would hasten the dietary shift towards meat-based food. The demand for animal products is indeed rising, especially in India and China (Nath et al., 2015). Withers et al. (2018) argue that in terms of sustainable nutrient management, dietary shifts in human food is a big challenge.

\subsubsection{Redistribution of the use of nutrients - a global challenge}

In order to restore the ecology of water systems as well as the productivity of degraded soils, there is a need to redistribute nutrients from the areas of excess application to the areas where the soil nutrient levels are insufficient (Carpenter and Bennett, 2011; MacDonald et al., 2011; Steffen and Stafford Smith, 2013). Such redistribution will help to increase crop yields and reduce regional nutrient surpluses and losses. There are different ways of redistributing nutrients, where one is to recover what has been lost, mostly $\mathrm{P}$ in sediments, but also others nutrients by harvesting water biomass of lakes and marine systems (Kahiluoto et al., 2011). Note, a large majority of nutrients in most of these resources could be an outcome of nutrient losses (emissions) from a surplus nutrient input. In other words, if we could reduce the nutrient surplus and losses, we may avoid the expensive recycling of these nutrient sources yet meeting the nutrient needs of the crops. There are different ways to reduce nutrient emissions to waters 
where one is increased recycling in the form of excreta reuse in crop production (Kahiluoto et al., 2015).

As discussed above, in order to increase local food production in many regions, there is a need to increase the nutrient supply in crop production. Our results show that the earth has enough nutrients to meet the crop nutrient need (Paper-I: Figure 1). There is potential to reduce the current use of synthetic nutrients if all nutrients from excreta are recycled. Additionally, our results show that not all countries have an oversupply in terms of nutrient input. Most of the countries in Africa, eastern Europe, and Southeast Asia need to enhance their nutrient supplies. Our results are in line with the results presented by Barrett and Bevis (2015), Mueller et al. (2012), Pradhan et al. (2015), and Tittonell and Giller (2013), who argue that in order to close crop yield gaps, the nutrient supply must be increased in some parts of the world. On the other hand, the results show that most of the European countries, the United States, and most countries in South America, the Middle East, and Asia must cut down on their input nutrients in order to reduce their nutrient surpluses. As discussed in Withers et al. (2018), opportunities to reduce nutrient surpluses by recycling are immense because the inputs in fertilizers and excreta still exceed current crop nutrient demand in many of the developed countries. Moreover, the large scale variation between national nutrient balances observed in our study (Paper-I: Figure 2) is in line with some regional studies, for example, the P balances in the EU member states (van Dijk et al., 2016). We observed that most western European countries have a positive nutrient balance. In contrast, the countries in central and eastern Europe show a negative nutrient balance. In summary, redistribution of excess excreta nutrients from the countries with a surplus to the countries with a deficit is required at a global scale.

4.2 Spatial separation -adjusting recycling strategies at local scales

If animal farms are very large, they may not have enough land to make efficient use of all the nutrients in the excreta. Similarly, large amounts of nutrients are present in human excreta in urban areas with limited or no agricultural land nearby (Chowdhury et al., 2014). It is believed that implementing cost-effective opportunities for recycling with increasing distances between crops and animal production areas is very challenging (Metson et al., 2016b). As such, the problem of nutrient surplus and deficits originate at local scales, which then lead to national and subnational nutrient imbalances. For example, Nord and Lanyon (2003) reported that in Pennsylvania (a small catchment), 20\% of the farms accounted for over $80 \%$ of $\mathrm{N}$ and P flows in the catchment, and these farms had large nutrient surpluses. They also reported that almost all the fodder and feed need of the animals in that catchment was provided by crops grown further away from the catchment. Local imbalances of nutrient need and supply have been shown at very high resolution for the entire country in Scotland (Leinonen et al., 2019) and in Denmark (Parchomenko and Borsky, 2018). Notably, subnational differences in nutrient supply and crop need shown in higher spatial resolution studies, for example, in Norway (Hanserud et al., 2015), in France (Senthilkumar et al., 2012), and England (Bateman et al., 2011) gave rise to nutrient surpluses at national scales in these countries, as observed by van Dijk et al. (2016). As mentioned, a large nutrient surplus is associated with an increased risk for negative impacts on other ecosystems (Mallin and Cahoon, 2003). Svanbäck et al. (2019) argued that the spatial separation of crop nutrient need and excreta nutrient supply is the primary cause of nutrient surpluses in the Baltic region. 
To improve the nutrient balance, we need to redistribute geographical excreta surpluses from the areas of intensive livestock production to the arable land (Klinglmair et al., 2015). We need to start such redistribution of excreta at the scales where these imbalances originate. For example, Nord and Lanyon (2003) suggested that in Pennsylvania, nutrient recycling within the catchment between neighboring crops and livestock farms would result in a reduced need for external inputs, and thus, the nutrient use efficiency in the catchment would increase. Similarly, almost all studies that have estimated spatial nutrient balances in a country suggested the need for a cost-effective and environmentally compatible logistics system for transport of surplus excreta to the deficit areas (Bateman et al., 2011; Hanserud et al., 2015; Leinonen et al., 2019; Senthilkumar et al., 2012).

Cost-optimized transport of excreta from the surplus region to the deficit region is an option to achieve the spatial balance of nutrient need and supply in a country. In order to minimize costs for excreta transports between the administrative districts of northwest Germany, transport optimization modeling has been used as a tool (Biberacher et al., 2009; Warnecke et al., 2010). The transport optimization has also been applied to transports within and between the counties of the Chesapeake Bay watershed in the United States (Ribaudo et al., 2011). The authors of those studies argued that optimizing the redistribution of surplus excreta is critical in promoting nutrient reuse at the minimum possible cost. Furthermore, transport optimization of excreta has been used to identify the cost-minimizing routes for reaching the croplands in Louisiana in the United States (Paudel et al., 2009). The studies mentioned here have used regional transport optimization at comparatively low resolutions. In our work, we have analyzed the optimized transport of excreta for an entire country and for reusing all excreta. We also analyzed the impact of input spatial data resolution on the results from the optimization model in terms of the need for excreta transports, transports distances, and costs.

\subsubsection{Substitution of synthetic fertilizers}

Redistributing excreta to meet the crop nutrient need could compensate for the use of synthetic fertilizers (Svanbäck et al., 2019) as well as greenhouse gas emissions (GHGs) related to the manufacturing of synthetic fertilizers (Brockmann et al., 2014; Lyng et al., 2015). Our results show that recycling all excreta and correcting imbalances between excreta supply and crop need would reduce the current use of synthetic fertilizers significantly, both in Sweden and Pakistan (Figure 3). Similarly, in Norway, excreta nutrients could potentially replace synthetic fertilizer completely, but only if the spatially separated excreta was redistributed among the counties in the country (Hanserud et al., 2015). In terms of GHGs emissions associated with synthetic fertilizer production, Wood and Cowie, (2004) argue that they are highly different for different production technologies. As such, there are also GHGs emissions related to transporting excreta. However, studies have shown that transport has a minor impact compared to the other processes related to GHGs emissions from excreta (Hanserud et al., 2017). It has been estimated that even relocating the animal production near to the crop production would not result in a substantial reduction in greenhouse gas emissions (Willeghems et al., 2016). 


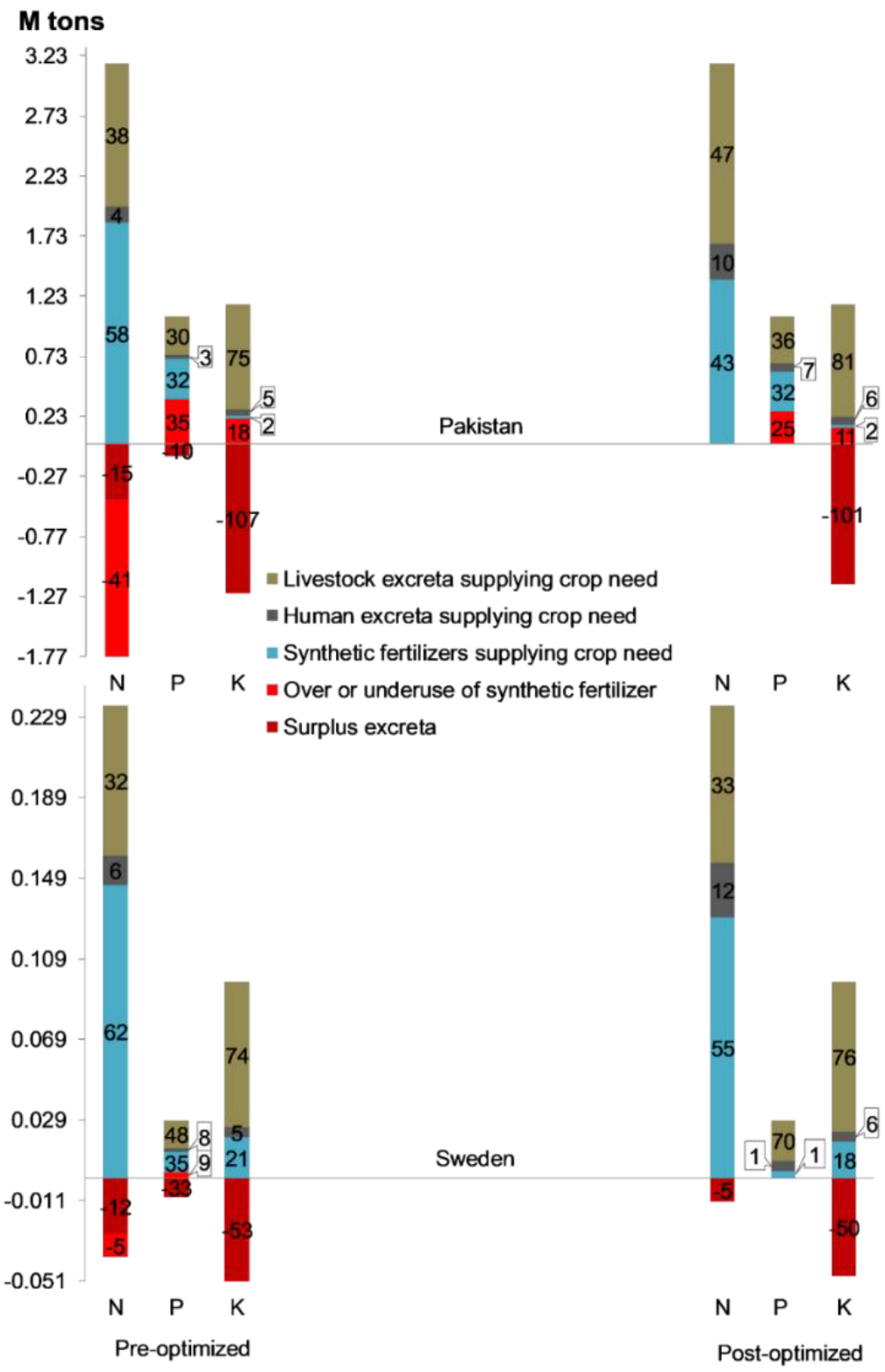

Figure 3: National nutrient balances associated with scenarios of pre- and post-optimized transport of surplus excreta at decimal degree resolution in Pakistan (top panel) and Sweden (bottom panel). The height of each bar above zero represents total crop nutrient need, while the height below zero represents the total nutrient surplus given the assumptions presented in section Economic Analysis Paper-IV. Colors represent the nutrient source used to fill the crop nutrient need above zero, while colors below zero represent the type of nutrient surplus. A gap between crop nutrient needs and supply is designated as red above 0 . The numbers in each colored column section represent the percentage of crop need that a source fulfills, where negative numbers (below the zero line) represent the surplus also expressed as a percentage of crop need. The figure is adapted from (Akram et al., 2019) 
The value of compensation of synthetic nutrients could be different in different scenarios, as it is based on different assumptions (Hanserud et al., 2017). For example, Brockmann et al. (2014) and Lyng et al. (2015) made a theoretical comparison of the plant-available nutrients in excreta that could replace an equivalent amount of nutrients in synthetic fertilizer. However, Hanserud et al., (2017) estimated for the potential of excreta to replace the requirement of synthetic nutrients in more practical terms. For example, an over-application of some nutrients in excreta (due to differences in the nutrient stoichiometry for crop nutrient need and excreta nutrient supply) would not replace the need for synthetic nutrients and thus was not considered in the estimates made by Hanserud et al., (2017). This thesis used a similar approach to estimate the potential for excreta nutrients to compensate for the use of synthetic fertilizers. The result shows that a large portion of the current use of synthetic fertilizers could be replaced with the complete recycling of excreta both in Sweden and Pakistan (Figure 3). Replacing the unnecessary use of synthetic fertilizers would reduce the nutrient surplus. Our results are in line with Svanbäck et al., (2019), who argue that increasing nutrient recycling would result in avoiding overapplication of fertilizers, and thus would reduce the nutrient surplus. In another study, it has been estimated that redistribution of excreta could potentially replace an annual import of $\mathrm{N}$ by 165,000 to 252,000 tons, and $\mathrm{P}$ by 70,000 to 120,000 tons in the Baltic Sea region (McCrackin et al., 2018).

Our results showed that there was an extreme imbalance between the ratio of total crops' nutrient need (N: P: K) and the ratio of total nutrient supplies, especially in Pakistan. In Pakistan, the input of $\mathrm{N}$ and $\mathrm{K}$ is far more than the input of $\mathrm{P}$. The imbalance in the ratio of the nutrient input not only causes crop yield gaps and economic loss but also has a tremendous impact on the biodiversity (Gress et al., 2007; Hillebrand and Lehmpfuhl, 2011; Moore et al., 2013). Our results also show that reusing all excreta reduces the surplus use of synthetic fertilizers and promotes balanced plant nutrition, i.e., the ratio between the nutrients. A balanced input ratio of nutrients is essential both from in order to harvest higher crop yields as well as to conserve agrobiodiversity.

\subsection{Importance of input data resolution}

Our global estimates of crop nutrient need and excreta nutrient supply are in line with other global studies. However, our results show that data resolution, coupled with different sets of assumptions, has an apparent impact on identifying and quantifying crop nutrient need and excreta nutrient supply. For example, crop P need that was calculated using low-resolution data, and different assumptions for 2007 in Sweden (Paper-I) is almost 1.6 times the crop nutrient need that was calculated using higher resolution data for the same year (Paper-III). For Pakistan, in 2010, the P crop need that was calculated using global data (Paper-I) is 0.56 times lower than the crop need that was estimated using the local high-resolution data (Paper-II). Similarly, such differences are visible in the estimates of nutrient amounts in excreta.

In order to promote a balance between crop nutrient need and excreta nutrient supply across the agricultural landscape, detailed spatial nutrient balance calculations can be used when formulating policies regarding sustainable nutrient use (de Vries and Hanley, 2016; Goulder and Schein, 2013). For example, the detailed spatial nutrient balances can be used to monitor nutrient emissions to waters from farmland (de Vries and Hanley, 2016). In this respect, the 
areas identified as having a nutrient surplus compared to the crop nutrient need may face some stricter regulations in order to control the excreta surplus, and thus the nutrient losses. Parchomenko and Borsky (2018) suggested similar regulations to achieve a stricter P use in areas with an oversupply in Denmark.

Regarding excreta redistribution, our results show that the resolution of data used in the spatial analyses has a large impact on the assessment of the total need for excreta transports, the total distances, and the patterns of the transports of excreta from surplus areas to deficit areas (Figure 2). A detailed spatial analysis makes it possible to distinguish between the areas needing shorter-distance transports and the areas where the excreta must be transported over longer distances (Figure 2C). Effective use of nutrient resources requires redistribution of excreta. However, depending on the specific local circumstances, the benefits of excreta distribution could be valued differently, and these benefits need to be investigated on a case-to case-basis (Hanserud et al., 2017). In cases where excreta transport is expensive, there is an opportunity for using excreta processing technology, either to decrease the weight of excreta by dewatering or to increase the value of the excreta by including other benefits, for example, using the energy content of excreta (Parchomenko and Borsky, 2018). We argue that high-resolution data gives more accurate estimates of the redistribution needs, transport distances, and costs as well as the ratio of fertilizer market value to transport cost. Achieving nutrient balances at a local scale would attract industry and government partners, who aim to increase the productive recycling of excreta in Sweden and Pakistan. 


\subsection{Concluding remarks}

Increasing nutrient input to increase food production may be an underlying cause of nutrientrelated environmental issues. However, the increased input was not caused by the innovative technologies, for example, the ability to manufacture synthetic fertilizers, but the policy and measures that have led to an injudicious overuse of nutrients in crop production. Evenson and Pingali (2007) argued that proper research and policies to incentivize judicious use of inputs were often missing in many places across the globe. As a result, the nutrient cycles are broken across the globe. As for now, the globe is not on the right path, i.e., the nutrient surplus has increased many folds in some regions, while other regions have an increased nutrient deficit (Paper-I). In other words, the current trends of nutrient inputs have jeopardized the sustainability of food production systems.

Studies have suggested that to close these nutrient cycles, major technological, social, and institutional innovations are needed (Aakkula and Leppänen, 2014; Ekholm and Mitikka, 2006; Haygarth et al., 2014). Most importantly, the globe needs strategies focusing on closing the nutrient cycles, i.e., to meet the targets of environmental safety as well as the targets of securing the food supply. This study highlights the potential to reduce the surplus use of nutrients in some regions while improving the nutrient supply in the other regions. The spatial nature of this analysis provided quantitative estimates of the surplus supply of nutrients as well as the estimates of nutrients deficits at multiple scales, i.e., local, national, and global scales. Further, the transport analysis part of the study suggests that redistribution of nutrients in excreta is costefficient in some areas but very costly in others.

First, the nutrient redistribution needs to be assured at the local scales in order to meet the national targets to cut the surplus use of synthetic fertilizers or to meet the crop nutrient need. Second, there is a possibility that the excreta redistribution needs to cross international borders to meet the crop nutrient in the countries having a nutrient deficit. Excreta transports over long distances could, in some cases, be economically expensive if the purpose is just to meet the crop nutrient need. However, considering other benefits, these excreta transports might become economically beneficial. For example, recovering nutrients from waters to return them healthy ecological states has been proposed as a solution to tackle eutrophication. Such solutions may include harvesting water biomass and removing the nutrient-rich sediments from lakes and marine systems (Kahiluoto et al., 2011). Note, these actions are often involving high costs.

If we can reduce the emissions of nutrients from agriculture (and other sources) to waters, it would still take a long time to bring the water bodies back to their health states. Savchuk and Wulff, (2009) argued that if the nutrient inputs to the Baltic Sea are reduced to the level they were a century ago, it would take more than 130 years for the sea to recover to the initial state. This means that there is an urgent need to reduce the nutrient input to water bodies to avoid unrecoverable damage to the ecosystems. Simultaneously, providing immediate access to enhanced food supplies to hungry people in the world is an urgent and important issue. In other words, we cannot wait to decide to reduce the nutrient input to waters and to increase nutrient access in the nutrient deficit areas to increase food production.

This study shows that the globe does not need more nutrients to increase the nutrient supply to increase food production. Instead, the globe needs to focus on redistributing nutrients already 
in the system. A complete excreta recycling is a win-win case that could remove the surplus supplies of nutrients of some countries while reducing the nutrient deficits of the other countries. This strategy to increase nutrient recycling has the potential to close the nutrientrelated crop yield gaps, even with reducing the current use of synthetic nutrients at the national as well as at the global scales. 


\section{Acknowledgments}

I am grateful to my supervisor Uno Wennergren. Thanks for putting your trust in me and giving me the opportunity to work on this exciting Ph.D. project. You are the most kind and the positive person I have seen in my academic life. I must say that as a supervisor, you are a person with a much broader approach and a vast vision. Thanks for your support, both moral and official, in completing my doctoral work.

Thank you, Karin Tonderski. Thank you for stimulating my interest in studying sustainable nutrient management. You and Jan-Olof Drangert have done that while teaching me the master's course Sustainable Sanitation in 2010. Thank you for accepting me as a Ph.D. student, being a co-supervisor. You are one of the best teachers I have met in my life. Thank you for all the support and help you have provided me to complete my work.

Thank you, Genevieve Metson. Thank you for coming in at the time when I was feeling stuck and hopeless in my doctoral studies. Your entry was like a big force to break all the barriers that were stopping me from moving forward. Thank you for being critical and constructive to help achieve my educational targets.

Thank you, Nils-Hassan Quttineh. Thanks for your support and patience while correcting my math equations. Thanks for taking the challenge to develop and run the excreta transport optimization model. Without having you, I would not have got the results I needed to complete my Ph.D. studies.

Thanks to all my colleagues at the division of TheoBio. You all are awesome people. You all are caring and supportive. Thanks to all my friends, especially Fahad Khan, Raja Babar, and Ali Ahmad Assakzai. Fahad Bhai and Raja Saab, thanks for being there and giving me the freedom to talk to you about my research life. You both are fantastic guys being a good friend and mentor. Ali Bhai, thanks for being there to solve my programming challenges in the Visual Basic.

Thanks to all my family members. Especially sisters Fozia Tabassum, Mamoona Kiran, brother Shahzad Ahmad, cousins Shawaiz Akhtar, Amman Ullah, and Irfan Anwer. You guys are a great source of moral support to help me proceed in my career.

Thanks to Gul E Leena, Arham, and Abiha. Gul E Leena, you are a great companion and a good friend. Arham and Abiha, you both are my life. You are an unlimited source of energy for me. Your cute smiling faces and beautiful little words have always been an effective cure during the depressive moments of my work.

A huge thanks to my parents, Muhammad Akram and Munawar Sultana. You are the complete source of love, encouragement, and never-ending support. You are the best blessing that I have from Almighty! My biggest motivation to proceed in my career is to see you both proud and happy. 


\section{References}

Aakkula, J., Leppänen, J., 2014. Follow-up study on the impacts of agri-environment measures (MYTVAS 3) Final Report 3/2014. Helsinki.

Akram, U., Quttineh, N.-H., Wennergren, U., Tonderski, K., Metson, G.S., 2019. Optimizing Nutrient Recycling From Excreta in Sweden and Pakistan: Higher Spatial Resolution Makes Transportation More Attractive. Front. Sustain. Food Syst. 3. https://doi.org/10.3389/fsufs.2019.00050

Albertsson, B., 2007. Riktlinjer för gödsling och kalkning 2008 [WWW Document]. URL http://www2.jordbruksverket.se/webdav/files/SJV/trycksaker/Pdf_jo/jo12_12.pdf (accessed 6.19.19).

Antonkiewicz, J., 2016. Chemical Innovation in Plant Nutrition in a Historical Continuum from Ancient Greece and Rome until Modern Times. https://doi.org/10.1515/cdem-20160002

Ashiq, M., 2010. Punjab main 75 faslon key Munafah bakhash kashat kari (Profitable cultivation of 75 crops in Punjab). Plant physiology section, Nizamat Amoor-e-kashat kari (Agronomy), Ayub Agriculture Research Institute, Faisalabad, Pakistan.

Aulie, R.P., 1970. Boussingault and the Nitrogen Cycle. Proc. Am. Philos. Soc. 114, 435479.

Barrett, christopher B., Bevis, L.E.M., 2015. The self-reinforcing feedback between low soil fertility and chronic poverty. Nat. Geosci. 8, 907-912. https://doi.org/10.1038/ngeo2591

Bateman, A., van der Horst, D., Boardman, D., Kansal, A., Carliell-Marquet, C., 2011. Closing the phosphorus loop in England: The spatio-temporal balance of phosphorus capture from manure versus crop demand for fertiliser. Resour. Conserv. Recycl. 55, 1146-1153. https://doi.org/10.1016/J.RESCONREC.2011.07.004

Bergendahl, J.A., Sarkis, J., Timko, M.T., 2018. Transdisciplinarity and the food energy and water nexus: Ecological modernization and supply chain sustainability perspectives.

Resour. Conserv. Recycl. 133, 309-319. https://doi.org/10.1016/j.resconrec.2018.01.001

Biberacher, M., Warnecke, S., Brauckmann, H.J., Broll, G., 2009. A linear optimisation model for animal farm manure transports in regions with high intensity animal farming. 18th World IMACS Congr. MODSIM09 Int. Congr. Model. Simul. Interfacing Model. Simul. with Math. Comput. Sci. Proc. 470-476.

Bloem, E., Albihn, A., Elving, J., Hermann, L., Lehmann, L., Sarvi, M., Schaaf, T., Schick, J., Turtola, E., Ylivainio, K., 2017. Contamination of organic nutrient sources with potentially toxic elements, antibiotics and pathogen microorganisms in relation to $\mathrm{P}$ fertilizer potential and treatment options for the production of sustainable fertilizers: A review. Sci. Total Environ. 607-608, 225-242. https://doi.org/10.1016/j.scitotenv.2017.06.274

BOS, 2014. Development statistics of Sindh 2014. Sindh Bureau of Statistics, Complex, ST13, Ch. Khaliq-u-Zaman Road, Block-8, Kehkashan Clifton, Karachi.

BOS, 2013. Development Statistics of Khyber Pakhtunkhwa 2011-12. Bureau of Statistics Khyber Pakhtunkhwa, Ground Floor, Benevolent Fund Building, Saddar Road Peshawar, Khyber Pakhtunkhwa.

BOS, 2011. Development Statistics of Balochistan 2011-12. Area \& Population Table 6. Bureau of Statistics Balochistan, Planning \& Development Department, Quetta. 
BOS, 2010. Punjab development statistics 2010. Bureau of Statistics Punjab, 65-Trade Centre Block, M.A Johar Town, Lahore.

Bouwman, A.F., Lee, D.S., Asman, W.A.H., Dentener, F.J., Hoek, K.W. Van Der, Olivier, J.G.J., Tg, N., 1997. A global high-resolution emission inventory for ammonia. Global Biogeochem. Cycles 11, 561-587.

Bouwman, L., Goldewijk, K.K., Van Der Hoek, K.W., Beusen, A.H.W., Van Vuuren, D.P., Willems, J., Rufino, M.C., Stehfest, E., 2013. Exploring global changes in nitrogen and phosphorus cycles in agriculture induced by livestock production over the 1900-2050 period. Proc. Natl. Acad. Sci. 110, 20882-20887. https://doi.org/10.1073/pnas.1012878108

Brockmann, D., Hanhoun, M., Négri, O., Hélias, A., 2014. Environmental assessment of nutrient recycling from biological pig slurry treatment - Impact of fertilizer substitution and field emissions. Bioresour. Technol. 163, 270-279. https://doi.org/10.1016/j.biortech.2014.04.032

Bruinsma, J., 2011. The resources outlook: by how much do land, water and crop yields need to increase by 2050?, in: Conforti, P. (Ed.), Looking Ahead in World Food and Agriculture - Perspectives to 2050. Food and Agriculture Organization of the United Nations, Rome, pp. 233-278.

Carpenter, S.R., 2003. Regime shifts in lake ecosystems: pattern and variation.

Carpenter, S.R., Bennett, E.M., 2011. Reconsideration of the planetary boundary for phosphorus. Environ. Res. Lett. 6. https://doi.org/10.1088/1748-9326/6/1/014009

CBS, 2012. Standardised calculation methods for animal manure and nutrients: Standard data 1990-2008. Henri Faasdreef 3122492 JP The Hague The Netherlands.

Chen, S., Ampelli, C., Centi, G., 2019. Electrochemical Dinitrogen Activation: To Find a Sustainable Way to Produce Ammonia. Stud. Surf. Sci. Catal. 178, 31-46. https://doi.org/10.1016/B978-0-444-64127-4.00002-1

Chowdhury, R.B., Moore, G.A., Weatherley, A.J., Arora, M., 2017. Key sustainability challenges for the global phosphorus resource, their implications for global food security, and options for mitigation. J. Clean. Prod. 140, 945-963.

https://doi.org/10.1016/j.jclepro.2016.07.012

Chowdhury, R.B., Moore, G.A., Weatherley, A.J., Arora, M., 2014. A review of recent substance flow analyses of phosphorus to identify priority management areas at different geographical scales. Resour. Conserv. Recycl. 83, 213-228.

https://doi.org/10.1016/j.resconrec.2013.10.014

Clark, M., Tilman, D., 2017. Comparative analysis of environmental impacts of agricultural production systems, agricultural input efficiency, and food choice. Environ. Res. Lett. 12. https://doi.org/10.1088/1748-9326/aa6cd5

Cordell, D., Drangert, J.O., White, S., 2009. The story of phosphorus: Global food security and food for thought. Glob. Environ. Chang. 19, 292-305. https://doi.org/10.1016/j.gloenvcha.2008.10.009

Dai, X., Karring, H., 2014. A determination and comparison of urease activity in feces and fresh manure from pig and cattle in relation to ammonia production and $\mathrm{pH}$ changes. PLoS One 9. https://doi.org/10.1371/journal.pone.0110402

de Vries, F.P., Hanley, N., 2016. Incentive-Based Policy Design for Pollution Control and 
Biodiversity Conservation: A Review. Environ. Resour. Econ. 63, 687-702. https://doi.org/10.1007/s10640-015-9996-8

De Vries, W., Kros, J., Kroeze, C., Seitzinger, S.P., 2013. Assessing planetary and regional nitrogen boundaries related to food security and adverse environmental impacts. Curr. Opin. Environ. Sustain. 5, 392-402. https://doi.org/10.1016/j.cosust.2013.07.004

Dillon, P.J., Rigler, F.H., 1974. The phosphorus-chlorophyll relationship in lakes1,2. Limnol. Oceanogr. 19, 767-773. https://doi.org/10.4319/1o.1974.19.5.0767

Dubin, H.J., Brennan, J.P., 2010. Combating Stem and Leaf Rust of Wheat: Historical Perspective, Impacts, and Lessons Learned, in: Spielman, D.J., Pandya-Lorch, R. (Eds.), Proven Successes in Agricultural Development A Technical Compendium to Millions Fed. International Food Policy Research Institute, Washington, D.C., pp. 31-66.

Edixhoven, J.D., Gupta, J., Savenije, H.H.G., 2014. Recent revisions of phosphate rock reserves and resources: A critique. Earth Syst. Dyn. 5, 491-507. https://doi.org/10.5194/esd-5-491-2014

Eisler, M.C., Lee, M.R.F., Tarlton, J.F., Martin, G.B., 2014. Steps to sustainable livestock. Nature 507, 32-34. https://doi.org/10.1038/507032a

EIU, 2014. Global Food Security Index.

Ekholm, P., Mitikka, S., 2006. Agricultural lakes in Finland: Current water quality and trends. Environ. Monit. Assess. 116, 111-135. https://doi.org/10.1007/s10661-006-7231-3

Eklind, Y., Kirchmann, H., 2000. Composting and storage of organic household waste with different litter amendments. II: nitrogen turnover and losses. Bioresour. Technol. 74, 125-133. https://doi.org/10.1016/S0960-8524(00)00005-5

Ellis, F., Freeman, H.A., 2004. Rural livelihoods and poverty reduction strategies in four African countries. J. Dev. Stud. 40, 1-30. https://doi.org/10.1080/00220380410001673175

Ericsson, J., 1988. Kväve och kvävegödsling. Swedish University of Agricultural Sciences, Uppsala.

Evans, A., Strezov, V., Evans, T.J., 2014. Anaerobic digestion. Biomass Process. Technol. 177-212. https://doi.org/10.1201/b17093

Evenson, R., Pingali, P., 2007. Handbook of Agricultural Economics. Elsevier, Amsterdam.

FAO/IIASA, 2010. Crop harvested area, yield and production.

FAO, 2017. World fertilizer trends and outlook to 2020. Food Agric. Organ. United Nations 66.

FAO, 2009a. How to Feed the World in 2050. Insights from an Expert Meet. FAO 2050, 135. https://doi.org/10.1111/j.1728-4457.2009.00312.x

FAO, 2009b. Global agriculture towards 2050. High Lev. Expert Forum-How to Feed world $20501-4$.

FAO, 2004a. The State of Food and Agriculture 2003-2004, Journal of Chemical Information and Modeling. Viale delle Terme di Caracalla, 00100 Rome, Italy.

FAO, 2004b. Fertilizer use by crop in Pakistan. Food Agric. Organ. United Nations 1-73.

FAOSTAT, 2019a. Livestock Manure: FracLoss_MMS_Country [WWW Document]. URL http://www.fao.org/faostat/en/\#data/EMN (accessed 10.23.19). 
FAOSTAT, 2019b. Live Animals [WWW Document]. URL http://www.fao.org/faostat/en/\#data/QA (accessed 10.23.19).

FAOSTAT, 2019c. Livestock Manure. N_ExcrRate_Country [WWW Document]. URL http://www.fao.org/faostat/en/\#data/EMN (accessed 10.23.19).

FAOSTAT, 2019d. Livestock Manure: TAM_Country [WWW Document]. URL http://www.fao.org/faostat/en/\#data/EMN (accessed 10.23.19).

FAOSTAT, 2019e. Annual population [WWW Document]. URL http://www.fao.org/faostat/en/\#data/OA (accessed 10.24.19).

FAOSTAT, 2019f. Food Balance Sheets [WWW Document]. URL http://www.fao.org/faostat/en/\#data/FBS (accessed 10.24.19).

FAOSTAT, 2019g. Crops [WWW Document]. URL http://www.fao.org/faostat/en/\#data/QC (accessed 10.25.19).

Fealy, R., Schröder, J.J., 2008. Assessment of manure transport distances and their impact on economic and energy costs, Proceedings / International Fertliser Society : 642. IFS, 228,

Federico, G., 2009. AGRICULTURAL INSTITUTIONS AND GROWTH, in: Feeding the World: An Economic History of Agriculture, 1800-2000. Princeton University Press, p. 183.

Fischer, R.A., 2015. Definitions and determination of crop yield, yield gaps, and of rates of change. F. Crop. Res. 182, 9-18. https://doi.org/10.1016/j.fcr.2014.12.006

Flotats, X., Bonmatí, A., Fernández, B., Magrí, A., 2009. Manure treatment technologies: Onfarm versus centralized strategies. NE Spain as case study. Bioresour. Technol. 100, 5519-5526. https://doi.org/10.1016/J.BIORTECH.2008.12.050

Freeze, B.S., Sommerfeldt, T.G., 1985. Breakeven hauling distances for beef feedlot manure in southern Alberta. Can. J. Soil Sci. 65, 687-693.

Geissler, B., Steiner, G., Mew, M.C., 2018. Clearing the fog on phosphate rock data Uncertainties, fuzziness, and misunderstandings. Sci. Total Environ. 642, 250-263. https://doi.org/10.1016/j.scitotenv.2018.05.381

Gerber, P., Chilonda, P., Franceschini, G., Menzi, H., 2005. Geographical determinants and environmental implications of livestock production intensification in Asia. Bioresour. Technol. 96, 263-276. https://doi.org/10.1016/j.biortech.2004.05.016

Gilbert, M., Nicolas, G., Cinardi, G., Van Boeckel, T.P., Vanwambeke, S., Wint, G.R.W., Robinson, T.P., 2018a. Global chickens distribution in 2010 (5 minutes of arc). https://doi.org/doi:10.7910/DVN/SUFASB

Gilbert, M., Nicolas, G., Cinardi, G., Van Boeckel, T.P., Vanwambeke, S., Wint, W.G.R., Robinson, T.P., 2018b. Global buffaloes distribution in 2010 (5 minutes of arc). https://doi.org/doi:10.7910/DVN/5U8MWI

Gilbert, M., Nicolas, G., Cinardi, G., Van Boeckel, T.P., Vanwambeke, S., Wint, W.G.R., Robinson, T.P., 2018c. Global cattle distribution in 2010 (5 minutes of arc). https://doi.org/doi:10.7910/DVN/GIVQ75

Gilbert, M., Nicolas, G., Cinardi, G., Van Boeckel, T.P., Vanwambeke, S., Wint, W.G.R., Robinson, T.P., 2018d. Global goats distribution in 2010 (5 minutes of arc). https://doi.org/doi:10.7910/DVN/OCPH42 
Gilbert, M., Nicolas, G., Cinardi, G., Van Boeckel, T.P., Vanwambeke, S., Wint, W.G.R., Robinson, T.P., 2018e. Global pigs distribution in 2010 (5 minutes of arc). https://doi.org/doi:10.7910/DVN/33N0JG

Gilbert, M., Nicolas, G., Cinardi, G., Van Boeckel, T.P., Vanwambeke, S., Wint, W.G.R., Robinson, T.P., 2018f. Global ducks distribution in 2010 (5 minutes of arc). https://doi.org/doi:10.7910/DVN/ICHCBH

Gilbert, M., Nicolas, G., Cinardi, G., Van Boeckel, T.P., Vanwambeke, S., Wint, W.G.R., Robinson, T.P., 2018g. Global horses distribution in 2010 (5 minutes of arc). https://doi.org/doi:10.7910/DVN/7Q52MV

Gonçalves, D.N.S., Gonçalves, C. de M., Assis, T.F. de, Silva, M.A. da, 2014. Analysis of the Difference between the Euclidean Distance and the Actual Road Distance in Brazil. Transp. Res. Procedia 3, 876-885. https://doi.org/https://doi.org/10.1016/j.trpro.2014.10.066

Goulder, L., Schein, A., 2013. Carbon taxes versus cap and trade: A critical review. Clim. Chang. Econ. 53, 1689-1699. https://doi.org/10.1017/CBO9781107415324.004

Goulding, K.W.T., 2016. Soil acidification and the importance of liming agricultural soils with particular reference to the United Kingdom. Soil Use Manag. 32, 390-399. https://doi.org/10.1111/sum.12270

Granstedt, A., 2000. Increasing the efficiency of plant nutrient recycling within the agricultural system as a way of reducing the load to the environment - experience from Sweden and Finland. Agric. Ecosyst. Environ. 80, 169-185. https://doi.org/10.1016/S0167-8809(00)00141-9

Greppa Näringen, 2012. Praktiska Råd: Din stallgödsel är värdefull 1-6.

Greppa Näringen, 2008. Verktyg i miljöarbetet behövs mer än någonsin! [WWW Document]. URL

http://www.greppa.nu/download/18.37e9ac46144f41921cd1a92d/1402565001964/2008_ Mar_GreppaNYTT.pdf (accessed 4.14.19).

Gress, S.E., Nichols, T.D., Northcraft, C.C., Peterjohn, W.T., 2007. Nutrient limitation in soils exhibiting differing nitrogen availabilities: What lies beyond nitrogen saturation? Ecology 88, 119-130. https://doi.org/10.1890/00129658(2007)88[119:NLISED]2.0.CO;2

Hanserud, O.S., Brod, E., Øgaard, A.F., Müller, D.B., Brattebø, H., 2015. A multi-regional soil phosphorus balance for exploring secondary fertilizer potential : the case of Norway 307-320. https://doi.org/10.1007/s10705-015-9721-6

Hanserud, O.S., Lyng, K.A., De Vries, J.W., Øgaard, A.F., Brattebø, H., 2017. Redistributing phosphorus in animal manure from a livestock-intensive region to an Arable region: Exploration of environmental consequences. Sustain. 9. https://doi.org/10.3390/su9040595

Harrison, J.A., Bouwman, A.F., Mayorga, E., Seitzinger, S., 2010. Magnitudes and sources of dissolved inorganic phosphorus inputs to surface fresh waters and the coastal zone: A new global model. Global Biogeochem. Cycles 24.

Hawkesford, M.J., 2012. Improving Nutrient Use Efficiency in Crops. eLS. https://doi.org/10.1002/9780470015902.a0023734

Haygarth, P.M., Jarvie, H.P., Powers, S.M., Sharpley, A.N., Elser, J.J., Shen, J., Peterson, 
H.M., Chan, N.I., Howden, N.J.K., Burt, T., Worrall, F., Zhang, F., Liu, X., Ekholm, P., Mitikka, S., Savchuk, O.P., Wulff, F., Sattari, S., Bouwman, A.F., Giller, K.., Van Ittersum, M.K., Haygarth, P.M., Jarvie, H.P., Powers, S.M., Sharpley, A.N., Elser, J.J., Shen, J., Peterson, H.M., Chan, N.I., Howden, N.J.K., Burt, T., Worrall, F., Zhang, F., Liu, X., Kahiluoto, H., Kuisma, M., Kuokkanen, A., Mikkilä, M., Linnanen, L., Steffen, W., Broadgate, W., Deutsch, L., Gaffney, O., Ludwig, C., 2014. Sustainable phosphorus management and the need for a long-term perspective: The legacy hypothesis. Environ. Sci. Technol. 48, 8417-8419. https://doi.org/10.1021/es502852s

Häyhä, T., Lucas, P.L., van Vuuren, D.P., Cornell, S.E., Hoff, H., 2016. From Planetary Boundaries to national fair shares of the global safe operating space - How can the scales be bridged? Glob. Environ. Chang. 40, 60-72.

https://doi.org/10.1016/j.gloenvcha.2016.06.008

Hazell, P.B.R., 2010. The Asian Green Revolution, in: Spielman, D.J., Pandya-lorch, R. (Eds.), Proven Successes in Agricultural Development A Technical Compendium to Millions Fed. International Food Policy Research Institute, Washington, DC, pp. 67-97.

Hecky, R.E., Kilham, P., 1988. Nutrient limitation of phytoplankton in freshwater and marine environments: A review of recent evidence on the effects of enrichment. Limnol. Oceanogr. 33, 796-822. https://doi.org/10.4319/lo.1988.33.4part2.0796

Hillebrand, H., Lehmpfuhl, V., 2011. Resource stoichiometry and consumers control the biodiversity-productivity relationship in pelagic metacommunities. Am. Nat. 178, 171181. https://doi.org/10.1086/660831

Horritt, M.S., Bates, P.D., 2001. Effects of spatial resolution on a raster based model of flood flow. J. Hydrol. 253, 239-249. https://doi.org/10.1016/S0022-1694(01)00490-5

Jakobsson, C., Steineck, S., 2012. Management of manure on the Farm: One of the Keys to the Future, in: Jakobsson, C. (Ed.), Sustainable Agriculture Ecosystem Health and Sustainable Agriculture 1. The Baltic University Programme, Uppsala University, 2012, p. 505 .

James, E.K., 2016. Nitrogen Fixation. Encycl. Appl. Plant Sci. 1, 271-277. https://doi.org/10.1016/B978-0-12-394807-6.00124-6

JBV, 2018a. Produktionsplatser för djurhållning [WWW Document]. URL http://www.jordbruksverket.se/etjanster/etjanster/etjansterforstod/kartorochgis/inspiretja nster/laddanerkartskikt.4.2c4b2c401409a334931bf0e.html

JBV, 2018b. Jordbruksblock [WWW Document]. URL http://www.jordbruksverket.se/etjanster/etjanster/etjansterforstod/kartorochgis/inspiretja nster/laddanerkartskikt.4.2c4b2c401409a334931bf0e.html

Jönsson, H., Eklind, Y., Albihn, A., Jarvis, A., Kylin, H., Nilsson, M.-L., Nordberg, Å., Pell, M., Schnürer, A., Schönning, C., Sundh, I., Sundqvist, J.-O., 2003. Samhällets organiska avfall - en resurs i kretsloppet (The organic waste in society - a resource in the circulation; in Swedish).

Jonsson, H., Stinzing, A.R., Vinneras, B., Salomon, E., 2004. Guidelines on the Use of Urine and Faeces in Crop Production. EcoSanRes Publ. Ser. 2, 1-35.

Jönsson, H., Vinnerås, B., 2004. Adapting the nutrient content of urine and faeces in different countries using FAO and Swedish data. Ecosan-Closing loop 623-626.

Jönsson, H., Vinnerås, B., Höglund, C., Stenström, T.A., Dalhammar, G., Kirchman, H., 2000. Källsorterad humanurin i kretslopp. Stockholm. 
Kahiluoto, H., Kuisma, M., Havukainen, J., Luoranen, M., Karttunen, P., Lehtonen, E., Horttanainen, M., 2011. Potential of agrifood wastes in mitigation of climate change and eutrophication - two case regions. Biomass Bioenergy 35, 1983-94.

Kahiluoto, H., Kuisma, M., Kuokkanen, A., Mikkilä, M., Linnanen, L., 2015. Local and social facets of planetary boundaries: Right to nutrients. Environ. Res. Lett. 10, 104013. https://doi.org/10.1088/1748-9326/10/10/104013

Kahiluoto, H., Kuisma, M., Kuokkanen, A., Mikkilä, M., Linnanen, L., 2014. Taking planetary nutrient boundaries seriously: Can we feed the people? Glob. Food Sec. 3, 1621. https://doi.org/10.1016/j.gfs.2013.11.002

Keplinger, K.O., Hauck, L.M., 2006. The economics of manure utilization: Model and application. J. Agric. Resour. Econ. 31, 414-440. https://doi.org/10.2307/40987326

Klinglmair, M., Lemming, C., Jensen, L.S., Rechberger, H., Astrup, T.F., Scheutz, C., 2015. Phosphorus in Denmark: National and regional anthropogenic flows. Resour. Conserv. Recycl. 105, 311-324. https://doi.org/10.1016/j.resconrec.2015.09.019

Leinonen, I., Eory, V., MacLeod, M., 2019. Applying a process-based livestock model to predict spatial variation in agricultural nutrient flows in Scotland. J. Clean. Prod. 209, 180-189. https://doi.org/10.1016/j.jclepro.2018.10.236

Lemley, D.A., Adams, J.B., 2019. Eutrophication. Encycl. Ecol. 86-90. https://doi.org/10.1016/B978-0-12-409548-9.10957-1

Leopold, A., 1943. A Sand County Almanac and Sketches Here and There. Oxford University Press, New York, NY, USA.

Lieth, H., 1975. Historical Survey of Primary Productivity Research, in: Lieth, H., Whittaker, R.H. (Eds.), Primary Productivity of the Biosphere. Springer-Verlag Berlin Heidelberg, p. 340. https://doi.org/10.1007/978-3-642-80913-2

Liu, J., You, L., Amini, M., Obersteiner, M., Herrero, M., Zehnder, A.J.B., Yang, H., 2010. A high-resolution assessment on global nitrogen flows in cropland. Proc. Natl. Acad. Sci. 107, 8035-8040. https://doi.org/10.1073/pnas.0913658107

Lumen, 2020. Urbanization and the Development of Cities [WWW Document]. Boundless Sociol. URL https://courses.lumenlearning.com/boundlesssociology/chapter/urbanization-and-the-development-of-cities/ (accessed 7.14.20).

Lyng, K.A., Modahl, I.S., Møller, H., Morken, J., Briseid, T., Hanssen, O.J., 2015. The BioValue Chain model: a Norwegian model for calculating environmental impacts of biogas value chains. Int. J. Life Cycle Assess. 20, 490-502. https://doi.org/10.1007/s11367-015-0851-5

MacDonald, G.K., Bennett, E.M., Potter, P.A., Ramankutty, N., 2011. Agronomic phosphorus imbalances across the world's croplands. Proc. Natl. Acad. Sci. U. S. A. 108, 30863091. https://doi.org/10.1073/pnas.1010808108

Mahler, R.L., 2004. Nutrients Plants Require for Growth.

Mallin, M.A., Cahoon, L.B., 2003. Industrialized animal production - A major source of nutrient and microbial pollution to aquatic ecosystems. Popul. Environ. 24, 369-385. https://doi.org/10.1023/A:1023690824045

Mccrackin, M.L., Gustafsson, B.G., Hong, B., Howarth, R.W., Humborg, C., Savchuk, O.P., Svanbäck, A., Swaney, D.P., 2018. Opportunities to reduce nutrient inputs to the Baltic Sea by improving manure use efficiency in agriculture. https://doi.org/10.1007/s10113- 
018-1308-8

Métioui, A., Matoussi, F., Trudel, L., 2016. The Teaching of Photosynthesis in Secondary School: A History of the Science Approach. J. Biol. Educ. 50, 275-289. https://doi.org/10.1080/00219266.2015.1085427

Metson, G.S., Bennett, E.M., Elser, J.J., 2012. The role of diet in phosphorus demand. Environ. Res. Lett. 7. https://doi.org/10.1088/1748-9326/7/4/044043

Metson, G.S., Cordell, D., Ridoutt, B., 2016a. Potential Impact of Dietary Choices on Phosphorus Recycling and Global Phosphorus Footprints: The Case of the Average Australian City. Front. Nutr. 3, 1-7. https://doi.org/10.3389/fnut.2016.00035

Metson, G.S., Lin, J., Harrison, J.A., Compton, J.E., 2017. Linking terrestrial phosphorus inputs to riverine export across the United States. Water Res. 124, 177-191. https://doi.org/10.1016/j.watres.2017.07.037

Metson, G.S., MacDonald, G.K., Haberman, D., Nesme, T., Bennett, E.M., 2016b. Feeding the Corn Belt: Opportunities for phosphorus recycling in U.S. agriculture. Sci. Total Environ. 542, 1117-1126. https://doi.org/10.1016/j.scitotenv.2015.08.047

Mihelcic, J.R., Fry, L.M., Shaw, R., 2011. Global potential of phosphorus recovery from human urine and feces. Chemosphere 84, 832-839. https://doi.org/10.1016/J.CHEMOSPHERE.2011.02.046

Mikołajczyk, I., 2009. Marek Porcjusz Katon. O gospodarstwie rolnym. (Marcus Porcius Cato. About the farm). Scientific Publisher of Nicolaus Copernicus University.

Mohajan, H., 2015. Planetary Boundaries Must not be Crossed for the Survival of Humanity. J. Environ. Treat. Tech. 3, 184-200.

Montgomery, D.R., 2007. Dirt: The Erosion of Civilizations, 1st ed. University of California Press.

Moore, C.M., Mills, M.M., Arrigo, K.R., Berman-Frank, I., Bopp, L., Boyd, P.W., Galbraith, E.D., Geider, R.J., Guieu, C., Jaccard, S.L., Jickells, T.D., La Roche, J., Lenton, T.M., Mahowald, N.M., Marañón, E., Marinov, I., Moore, J.K., Nakatsuka, T., Oschlies, A., Saito, M.A., Thingstad, T.F., Tsuda, A., Ulloa, O., 2013. Processes and patterns of oceanic nutrient limitation. Nat. Geosci. 6, 701-710. https://doi.org/10.1038/ngeo1765

Morgan, J.B., 2013. Plant-Soil Interactions: Nutrient Uptake. Nat. Educ. Knowl. 4.

Mueller, N.D., Gerber, J.S., Johnston, M., Ray, D.K., Ramankutty, N., Foley, J.A., 2013. Corrigendum: Closing yield gaps through nutrient and water management. Nature 494, 390-390. https://doi.org/10.1038/nature11907

Mueller, N.D., Gerber, J.S., Johnston, M., Ray, D.K., Ramankutty, N., Foley, J.A., 2012. Closing yield gaps through nutrient and water management. Nature 490, 254-257. https://doi.org/10.1038/nature11420

Mylona, P., Pawlowski, K., Bisseling, T., 1995. Symbiotic Nitrogen Fixation. Plant Cell 7.

Nath, R., Luan, Y., Yang, W., Yang, C., Chen, W., Li, Q., Cui, X., 2015. Changes in arable land demand for food in India and China: A potential threat to food security. Sustain. 7, 5371-5397. https://doi.org/10.3390/su7055371

NFDC, 2010. Statistics. National Fertilizer Development Centre, Street No. 1, H-8/1, P.O. Box 3104 Islamabad, Pakistan.

Nicholson, F.A., Humphries, S., Anthony, S.G., Smith, S.R., Chadwick, D., Chambers, B.J., 
2012. A software tool for estimating the capacity of agricultural land in England and Wales for recycling organic materials (ALOWANCE). Soil Use Manag. 28, 307-317.

Nilsson, A.K., 2013. Regulating Zero Eutrophication. Swedish Law on Controlling Emissions of Nutrients into the Baltic Sea.

Nilsson, D., 2010. Simulation and cost analysis of systems for handling of fuel straw - applied to a heating plant in Skåne.

Olsson, H., Andersson, J., Edström, M., Rogstrand, G., Persson, P., Andersson, L., Bobeck, S., Assarsson, A. Benjaminsson, A., Jansson, A. Alexandersson, L., Thorell, K., Assarsson, A., Benjaminsson, A., Jansson, A., Alexandersson, L., Thorell, K., 2014. Samrötning av hästgödsel med nötflytgödsel. Uppsala.

Parchomenko, A., Borsky, S., 2018. Identifying phosphorus hot spots: A spatial analysis of the phosphorus balance as a result of manure application. J. Environ. Manage. 214, 137148. https://doi.org/10.1016/J.JENVMAN.2018.01.082

Paudel, K.P., Bhattarai, K., Gauthier, W.M., Hall, L.M., 2009. Geographic information systems (GIS) based model of dairy manure transportation and application with environmental quality consideration. Waste Manag. 29, 1634-1643. https://doi.org/10.1016/j.wasman.2008.11.028

PAULI, F.W., 1933. HUMUS AND PLANT (The Direct Humus Effect). Sci. Prog. 49, 427439.

PBS, 2012. Agricultural Census 2010 - Pakistan Report. Pakistan Bureau of Statistics, Statistics House, Plot \# 21, Mauve Area, G-9/1, Islamabad, Pakistan.

PBS, 2006. Pakistan Livestock Census 2006. Pakistan Bureau of Statistics, Statistics House, Plot \# 21, Mauve Area, G-9/1, Islamabad, Pakistan.

Pimentel, D., Pimentel, M., 2008. Food, Energy, and Society, 3rd ed. CRC Press (Taylor and Drancis Group), Boca Raton, Florida USA.

Pradhan, P., Fischer, G., Van Velthuizen, H., Reusser, D.E., Kropp, J.P., 2015. Closing yield gaps: How sustainable can we be? PLoS One 10, 1-18. https://doi.org/10.1371/journal.pone.0129487

Price, T.., Gebauer, A.B., 1995. New Perspectives On The Transitions to Agriculture, in: Last Hunters, First Farmers: New Perspectives on the Prehistoric Transition to Agriculture. School of American Research Press.

Prikhodko, D., Zrilyi, O., 2013. Review of the wheat sector and grain storage issues.

Ribaudo, M., Kaplan, J.D., Christensen, L.A., Gollehon, N., Johansson, R., Breneman, V.E., Aillery, M., Agapoff, J., Peters, M., 2011. Manure Management for Water Quality Costs to Animal Feeding Operations of Applying Manure Nutrients to Land. SSRN Electron. J. https://doi.org/10.2139/ssrn.757884

Robinson, T., Conchedda, G., 2011. Global Livestock Production Systems v.5 [WWW Document]. URL

http://www.fao.org/geonetwork/srv/en/metadata.show?id=38040\&currTab=simple

Robinson, T.P., Thornton, P., Franceschini, G., Kruska, R., Chiozza, F., Notenbaert, A., Cecchi, G., Herrero, M., Epprecht, M., Fritz, S., You, L., Conchedda, G., See, L., 2018. Global distribution of ruminant livestock production systems V5 (5 minutes of arc). https://doi.org/doi:10.7910/DVN/WPDSZE 
Robinson, T.P., Wint, G.R.W., Conchedda, G., Van Boeckel, T.P., Ercoli, V., Palamara, E., Cinardi, G., D’Aietti, L., Hay, S.I., Gilbert, M., 2014. Mapping the Global Distribution of Livestock. PLoS One 9, e96084.

Robson, B.J., 2014. State of the art in modelling of phosphorus in aquatic systems: Review, criticisms and commentary. Environ. Model. Softw. 61, 339-359.

https://doi.org/10.1016/j.envsoft.2014.01.012

Rockström, J., Steffen, W., Noone, K., Persson, Å., Chapin, F.S., Lambin, E.F., Lenton, T.M., Scheffer, M., Folke, C., Schellnhuber, H.J., Nykvist, B., de Wit, C.A., Hughes, T., van der Leeuw, S., Rodhe, H., Sörlin, S., Snyder, P.K., Costanza, R., Svedin, U., Falkenmark, M., Karlberg, L., Corell, R.W., Fabry, V.J., Hansen, J., Walker, B., Liverman, D., Richardson, K., Crutzen, P., Foley, J.A., III, F.S.C., Lambin, E.F., Lenton, T.M., Scheffer, M., Folke, C., Schellnhuber, H.J., Nykvist, B., Wit, C.A. de, Hughes, T., Leeuw13, S. van der, Rodhe14, H., , Sverker Sörlin1, 15, K., P., Snyder16, , Robert Costanza1, 17, Uno Svedin1, Malin Falkenmark1, 18, , Louise Karlberg1, 2, Corell19, R.W., , Victoria J. Fabry20 , James Hansen21 , Brian Walker1, 22, Diana Liverman23, 24, Katherine Richardson25, P.C., Foley27, J.A., Persson, 2009. A safe operating space for humanity. Nature 461, 472-475. https://doi.org/10.1038/461472a

Rosegrant, M.W., Hazell, P.B.R., 2000. Transforming the rural Asia economy: The unfinished revolution. Oxford University Press, Hong Kong:

Sanchez, P.A., 2002. Soil fertility and hunger in Africa. Science (80-. ). 295, 2019-2020. https://doi.org/10.1126/science.1065256

Savchuk, O.P., Wulff, F., 2009. Long-term modeling of large-scale nutrient cycles in the entire Baltic Sea. Hydrobiologia 629, 209-224. https://doi.org/10.1007/s10750-0099775-z

SCB, 2010. avgränsningar av koncentrerad bebyggelse [WWW Document]. URL http://www.scb.se/hitta-statistik/regional-statistik-och-kartor/geodata/oppna-geodata/

Schindler, D.W., 1974. Eutrophication and recovery in experimental lakes: Implications for lake management. Science (80-. ). 184, 897-899.

https://doi.org/10.1126/science.184.4139.897

Schröder, J.J., Cordell, D., Smit, A.L., Rosemarin, A., 2010. Sustainable use of phosphorus. Wageningen Plant ... 140.

Senthilkumar, K., Nesme, T., Mollier, A., Pellerin, S., 2012. Regional-scale phosphorus flows and budgets within France: The importance of agricultural production systems. Nutr. Cycl. Agroecosystems 92, 145-159. https://doi.org/10.1007/s10705-011-9478-5

Sharpley, A., Kleinman, P., Jarvie, H., Flaten, D., 2016. Distant views and local realities: the limits of global assessments to restore the fragmented phosphorus cycle. Agric. Environ. Lett. 1, 160024. https://doi.org/doi:10.2134/ael2016.07.0024

Sheldrick, W., Keith Syers, J., Lingard, J., 2003. Contribution of livestock excreta to nutrient balances. Nutr. Cycl. Agroecosystems 66, 119-131. https://doi.org/10.1023/A:1023944131188

Shigaki, F., Sharpley, A., Prochnow, L.I., 2006. Animal-based agriculture, phosphorus management and water quality in Brazil: options for the future. Sci. Agric. 63, 194-209. https://doi.org/10.1590/S0103-90162006000200013

Singh, B., Schulze, D.G., 2005. Soil Minerals and Plant Nutrition. Nat. Educ. Knowl. 6. 
Smaling, E., Moctar, T., de Ridder, N., 2006. Fertilizer Use and the Environment in Africa : Friends or Foes? Backgr. Pap. Prep. African Fertil. Summit.

Smith, O., Momber, G., Bates, R., Garwood, P., Fitch, S., Pallen, M., Gaffney, V., Allaby, R.G., 2015. Sedimentary DNA from a submerged site reveals wheat in the British Isles 8000 years ago. Science (80-. ). 2, 998-1001. https://doi.org/10.1126/science.1261278

SOFI, 2005. The state of food insecurity in the world, Actividad Dietetica. https://doi.org/10.1016/S1138-0322(09)71733-X

Solaiman, S., Ahmed, N., 2006. Plant nutrition management for better farmer livelihood, food security and environment, in: IMPROVING PLANT NUTRIENT MANAGEMENT FOR BETTER FARMER LIVELIHOODS, FOOD SECURITY AND ENVIRONMENTAL SUSTAINABILITY. Beijing, pp. 58-72.

Sparks, D.L., 2006. Historical Aspects of Soil Chemistry, in: Warkentin, B.P. (Ed.), Footprints in the Soil: People and Ideas in Soil History. Elsevier, Oxford, p. 309.

Spoehr, H.A., 1919. The Development of Conceptions of Photosynthesis Since Ingen-Housz. Sci. Mon. 9, 32-46.

Starck, Z., 2014. FIZJOLOGIA ROŚLIN: JAK BYŁO WCZORAJ, JAK JEST DZIŚ, A CO PRZYNIESIE JUTRO? Kosmos. Probl. Nauk Biol. 63, 569-589.

Statistics Sweden, 2017. Population by region, marital status, age and sex. Year 1968 - 2016 [WWW Document]. URL

http://www.statistikdatabasen.scb.se/pxweb/en/ssd/START_BE_BE0101_BE0101A/ BefolkningNy/?rxid=86abd797-7854-4564-9150-c9b06ae3ab07\# (accessed 1.9.18).

Statistics Sweden, 2011. Use of arable land by municipality and crop. Year 1981, 1985, 1989 1995, 1999- 2007 [WWW Document]. URL

http://www.statistikdatabasen.scb.se/pxweb/en/ssd/START_JO_JO0104/AkerArealGr odaK/?rxid=86abd797-7854-4564-9150-c9b06ae3ab07\# (accessed 1.9.18).

Statistics Sweden, 2008. Livestock by municipality and type of animal. Year 1981, 1985, 1989-1995, 1999, 2003, 2005, 2007 [WWW Document]. URL

http://www.statistikdatabasen.scb.se/pxweb/en/ssd/START_JO_JO0103/HusdjurK/?rx id=86abd797-7854-4564-9150-c9b06ae3ab07\# (accessed 1.10.18).

Steffen, W., Richardson, K., Rockström, J., Cornell, S.E., Fetzer, I., Bennett, E.M., Biggs, R., Carpenter, S.R., De Vries, W., De Wit, C.A., Folke, C., Gerten, D., Heinke, J., Mace, G.M., Persson, L.M., Ramanathan, V., Reyers, B., Sörlin, S., 2015. Planetary boundaries: Guiding human development on a changing planet. Science (80-. ). 347. https://doi.org/10.1126/science.1259855

Steffen, W., Stafford Smith, M., 2013. Planetary boundaries, equity and global sustainability: Why wealthy countries could benefit from more equity. Curr. Opin. Environ. Sustain. 5, 403-408. https://doi.org/10.1016/j.cosust.2013.04.007

Sultana, A., Kumar, A., 2014. Development of tortuosity factor for assessment of lignocellulosic biomass delivery cost to a biorefinery. Appl. Energy 119, 288-295. https://doi.org/10.1016/j.apenergy.2013.12.036

Svanbäck, A., McCrackin, M.L., Swaney, D.P., Linefur, H., Gustafsson, B.G., Howarth, R.W., Humborg, C., 2019. Reducing agricultural nutrient surpluses in a large catchment - Links to livestock density. Sci. Total Environ. 648, 1549-1559.

https://doi.org/10.1016/j.scitotenv.2018.08.194 
Swedish Board of Agriculture, JBV, 2017. Jordart och växtnäringstillstånd i åkermarken [WWW Document]. URL

http://www.jordbruksverket.se/amnesomraden/miljoklimat/miljoutvarderingarforsokochu tveckling/jordartiakermark.4.23f3563314184096e 0d2b77.html (accessed 1.15.18).

Tenkorang, F., Lowenberg-Deboer, J., 2009. Forecasting long-term global fertilizer demand. Nutr. Cycl. Agroecosystems 83, 233-247. https://doi.org/10.1007/s10705-008-9214-y

Teravaninthorn, S., Raballand, G., 2008. Transport Prices and Costsin Africa: A Review of the International Corridors, Directions in Development - Infrastructure. The World Bank, Washington, D.C. https://doi.org/doi:10.1596/978-0-8213-7650-8

Thaler, S., Zessner, M., Weigl, M., Rechberger, H., Schilling, K., Kroiss, H., 2015. Possible implications of dietary changes on nutrient fluxes, environment and land use in Austria. Agric. Syst. 136, 14-29. https://doi.org/10.1016/j.agsy.2015.01.006

Tilman, D., Balzer, C., Hill, J., Befort, B.L., 2011. Global food demand and the sustainable intensification of agriculture. Proc. Natl. Acad. Sci. 108, 20260-20264. https://doi.org/10.1073/pnas.1116437108

Tilman, D., Clark, M., 2014. Global diets link environmental sustainability and human health. Nature 515, 518-522. https://doi.org/10.1038/nature13959

Tittonell, P., Giller, K.E., 2013. When yield gaps are poverty traps: The paradigm of ecological intensification in African smallholder agriculture. F. Crop. Res. 143, 76-90. https://doi.org/10.1016/j.fcr.2012.10.007

Trémolières, J., Bonfilis, S., Carré, L., Sautier, C., 1961. Une méthode d'étude de la digistibilité chez l'homme, le fécalogramme. Nutritio et Dieta. Eur. Rev. Nutr. Diet. 3, 281-289.

Trimmer, J.T., Guest, J.S., 2018. Recirculation of human-derived nutrients from cities to agriculture across six continents. Nat. Sustain. 1, 427-435. https://doi.org/10.1038/s41893-018-0118-9

UN, 2006. The Millennium Development Goals Report 2006. Millenn. Dev. Goals Rep. 2006. https://doi.org/10.18356/6cd11401-en

van der Ploeg, R.R., Böhm, W., Kirkham, M.B., 1999. On the Origin of the Theory of Mineral Nutrition of Plants and the Law of the Minimum. Soil Sci. Soc. Am. J. 63, 1055-1062. https://doi.org/10.2136/sssaj1999.6351055x

van Dijk, K.C., Lesschen, J.P., Oenema, O., 2016. Phosphorus flows and balances of the European Union Member States. Sci. Total Environ. 542, 1078-1093. https://doi.org/10.1016/J.SCITOTENV.2015.08.048

Van Ittersum, M.K., Cassman, K.G., Grassini, P., Wolf, J., Tittonell, P., Hochman, Z., 2013. Yield gap analysis with local to global relevance-A review. F. Crop. Res. 143, 4-17. https://doi.org/10.1016/j.fcr.2012.09.009

van Puijenbroek, P.J.T.M., Beusen, A.H.W., Bouwman, A.F., 2019. Global nitrogen and phosphorus in urban waste water based on the Shared Socio-economic pathways. J. Environ. Manage. 231, 446-456. https://doi.org/10.1016/j.jenvman.2018.10.048

Vollenweider, R.A., 1968. Scientific fundamentals of the eutrophication of lakes and flowing waters, with particular reference to nitrogen and phosphorus as factors in eutrophication. Paris (France).

Warnecke, S., Biberacher, M., Brauckmann, H., Broll, G., 2010. Nutrient best management 
practices need regional material flow management for soil protection. World 168-171.

Weisdorf, J.L., 2005. FROM FORAGING TO FARMING: EXPLAINING THE NEOLITHIC REVOLUTION. J. Econ. Surv. 19. https://doi.org/10.1016/S0363-3268(04)22001-8

Westerman, P.W., Bicudo, J.R., 2005. Management considerations for organic waste use in agriculture. Bioresour. Technol. 96, 215-221. https://doi.org/10.1016/j.biortech.2004.05.011

Willeghems, G., De Clercq, L., Michels, E., Meers, E., Buysse, J., 2016. Can spatial reallocation of livestock reduce the impact of GHG emissions? Agric. Syst. 149, 11-19. https://doi.org/10.1016/j.agsy.2016.08.006

Wilson, K., 2014. Justus von Liebig and the birth of modern biochar. Biochar.

Wilson, M., 2018. Manure characteristics [WWW Document]. URL https://extension.umn.edu/manure-land-application/manure-characteristics\#nitrogen817860 (accessed 4.4.19).

Withers, P.J.A., Doody, D.G., Sylvester-Bradley, R., 2018. Achieving sustainable phosphorus use in food systems through circularisation. Sustain. 10, 1-17. https://doi.org/10.3390/su10061804

Withers, P.J.A., Elser, J.J., Hilton, J., Ohtake, H., Schipper, W.J., Van Dijk, K.C., 2015a. Greening the global phosphorus cycle: How green chemistry can help achieve planetary P sustainability. Green Chem. 17, 2087-2099. https://doi.org/10.1039/c4gc02445a

Withers, P.J.A., van Dijk, K.C., Neset, T.S.S., Nesme, T., Oenema, O., Rubæk, G.H., Schoumans, O.F., Smit, B., Pellerin, S., 2015b. Stewardship to tackle global phosphorus inefficiency: The case of Europe. Ambio 44, 193-206. https://doi.org/10.1007/s13280014-0614-8

Wood, S., Cowie, A., 2004. A Review of Greenhouse Gas Emission Factors for Fertiliser Production.

WSPA, 2012. Food Security and Livestock Production and Consumption Options for 2050 20.

Zhang, B., Tian, H., Lu, C., Dangal, S.R.S., Yang, J., Pan, S., 2017. Global manure nitrogen production and application in cropland during 1860-2014: A 5 arcmin gridded global dataset for Earth system modeling. Earth Syst. Sci. Data 9, 667-678. https://doi.org/10.5194/essd-9-667-2017

Zillén, L., Conley, D.J., Andrén, T., Andrén, E., Björck, S., 2008. Past occurrences of hypoxia in the Baltic Sea and the role of climate variability, environmental change and human impact. Earth-Science Rev. 91, 77-92.

https://doi.org/https://doi.org/10.1016/j.earscirev.2008.10.001 


\section{Papers}

The papers associated with this thesis have been removed for copyright reasons. For more details about these see:

http://urn.kb.se/resolve?urn=urn:nbn:se:liu:diva-168369 


\section{FACULTY OF SCIENCE AND ENGINEERING}

Linköping Studies in Science and Technology, Dissertation No. 2061, 2020

Department of Physics, Chemistry, and Biology

Linköping University

SE-581 83 Linköping, Sweden

www.liu.se 